\title{
The Canary Islands origin: a unifying model
}

\author{
F. Anguita , F. Hernán \\ ${ }^{a}$ Departamento de Petrología y Geoquímica, Universidad Complutense, 28040 Madrid, Spain \\ ${ }^{\mathrm{b}}$ Departamento de Edafología y Geología, Universidad de La Laguna, 38204 La Laguna (Canary Islands), Spain
}

Received 14 September 1999; received in revised form 6 March 2000; accepted 6 March 2000

\begin{abstract}
A new model, partially based on the three most widely cited previous hypotheses, is proposed to explain the genesis of the Canary Islands. From the hotspot hypothesis it retains the notion that the islands originated from a thermal anomaly in the mantle. From the propagating fracture hypothesis it takes the critical role of regional fractures in the onset of magmatism. The uplifted block hypothesis contributes with the notion that the islands are in their present freeboard attitude due to the action of tectonic forces.

The main drawbacks of the three preceding hypotheses are solved within this unifying approach: the thermal anomaly is an upper mantle residue from an old plume, and therefore it does not carry (or does it in a highly diluted form) the typical geophysical and geochemical plume signatures; the fractures are well developed on the continental and oceanic crust, but not in the extremely thick sedimentary pile between the Canary Islands and Africa; and the Canary Islands uplift took place through transpressive shears, and not by means of purely reverse faults. This unifying model, which integrates the thermal and tectonic histories of the lithosphere and the sublithospheric mantle, is considered to be a valid approach to a number of volcanic areas where, as has been highlighted in recent years, pure hotspot or pure fracture models are found wanting to explain oceanic or (less frequently) continental volcanic lines.
\end{abstract}

Keywords: Canary islands; hotspots; fracture magmatism

\section{Introduction}

The Canary Islands are a locus classicus of the science of Volcanology. Extensively studied from the 19th century on, they feature characteristics that make them unique among the volcanic oceanic island groups. The present hypotheses on the Canary Islands origin have in common that they were born in the aftermath of the mobilist geologic revolution. Paramount among them is the mantle plume hvoothesis. developed by Morgan (1971) on Wilson's (1963) hotspot concept. Equally anchored in the global frameworks of the seventies are the propagating fracture hypothesis (Anguita and Hernán, 1975) and the concepts of the Canary Islands as a local extensional ridge (Fúster, 1975) or as a set of uplifted tectonic blocks (Araña and Ortiz, 1986).

Of these four, only the plume hypothesis has been refurbished by its supporters during the last decade (Holik et al., 1991; Hoernle and Schmincke, 1993; Hoernle et al., 1995; Carracedo et al., 1998). It could therefore be concluded that this is the only presently accepted genetic model for the archipelago, but the real situation is slightly more complicated. Every hypothesis, including the several plume 


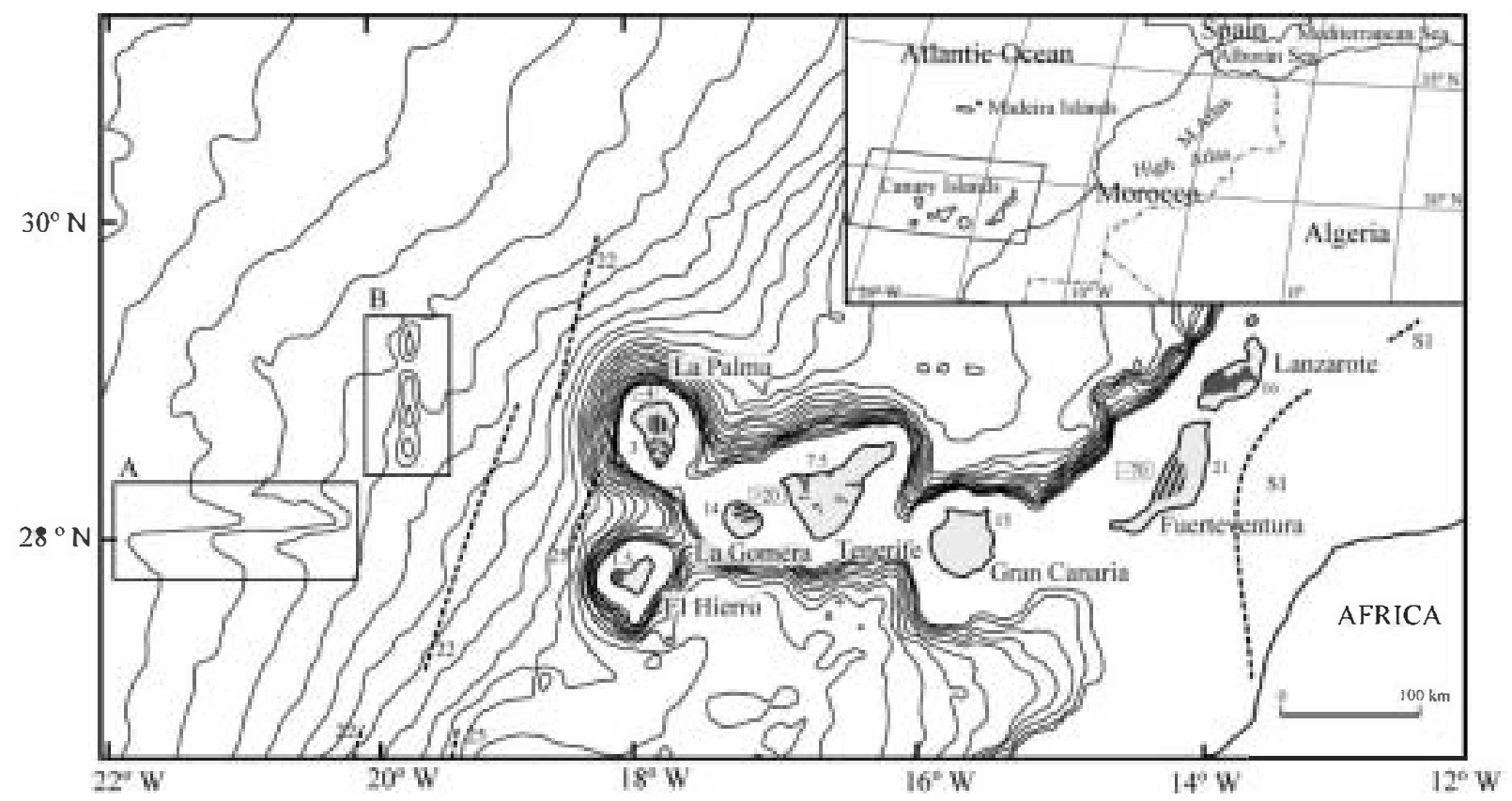

Fig. 1. A map of the Canary Islands showing some bathymeric (contours at $100 \mathrm{~m}$ intervals but only at depths greater than $2.5 \mathrm{~km}$ ), chronological, an eruptive activity data. In dark grey, terrain covered by historical eruptions. Striped, basal complexes (swipe directions in the azimuth of the sheeted dike complex). Numbers indicate the ages (Ma) of the oldest subaerial outcrops; when in boxes, the ages of the basal complexes. Boxes A and B underline tectonic signatures: A is a straight, $30 \mathbf{k m}$-long submarine canyon, and the site of a $M=6.2$ quake which happened in 1959. B is a $200 \mathrm{~km}$-long seamount line parallel to the swike of the sheeted dike complex of La Palma, the nearest island.

variants, suffered since it was propesed from inconsistencies with the løcal and regional ge $\bullet \bullet \log$ : the fact is that the Canary Islands, like a number of $\bullet$ ther midplate volcanic chains, are not yet well understood. This has become even more evident as the amount -f new data has increased at an ever growing pace. The list of new evidence arising in this decade is substantial, and includes new information on the sublithospheric mantle of the Canary Islands and surrounding regions; advances in the geochemistry - mantle source areas; the first thorøugh tectonic reconnaissance of several islands, and of the neighbøuring Mørøcc areas as well; a number of new marine geophysics data sets; and the many recent geochronøløgical investigations on Canary Islands røcks. These majør advances now permit an •verhauling of the former hypotheses; it is our contention that this hølistic vision can be used as the basis of a new, unifying model in which the main obstacles formerly encountered by the previøus ideas can be

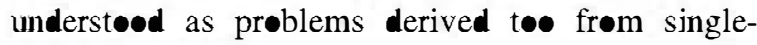
sided approaches.
T• evaluate the hypotheses that try to explain the ge logy of the islands, we must begin with a short ge • $\bullet$ gic description of the archipelag• (see Schmincke, 1973, 1976, 1982, for general backgrøund and further references). The Canary Islands are a røughly linear $500 \mathrm{~km}$ long chain (almost exactly the same size as the Hawaiian group) formed by seven islands (Fig. 1), all but one of which have been active in the last million year; four of them (three located at both ends of the chain, and one at its centre) show a record of enuptions in the last five centuries. As in ther volcanic islands grøups, the most complete sections consist of three types of units: (1) basal complexes (or pre-shield stage), composed of turbiditic sediments intruded by sheeted dike swarms, and by plutonics ranging from pyroxenites to carbonatites; (2) shield constructs; and (3) post-shield cones. The successive stages, which seem to represent one or more batches of new magma from the mantle, are commonly separated frøm each $\bullet$ ther by time gaps of several milliøns of years løng; there are, morever, 


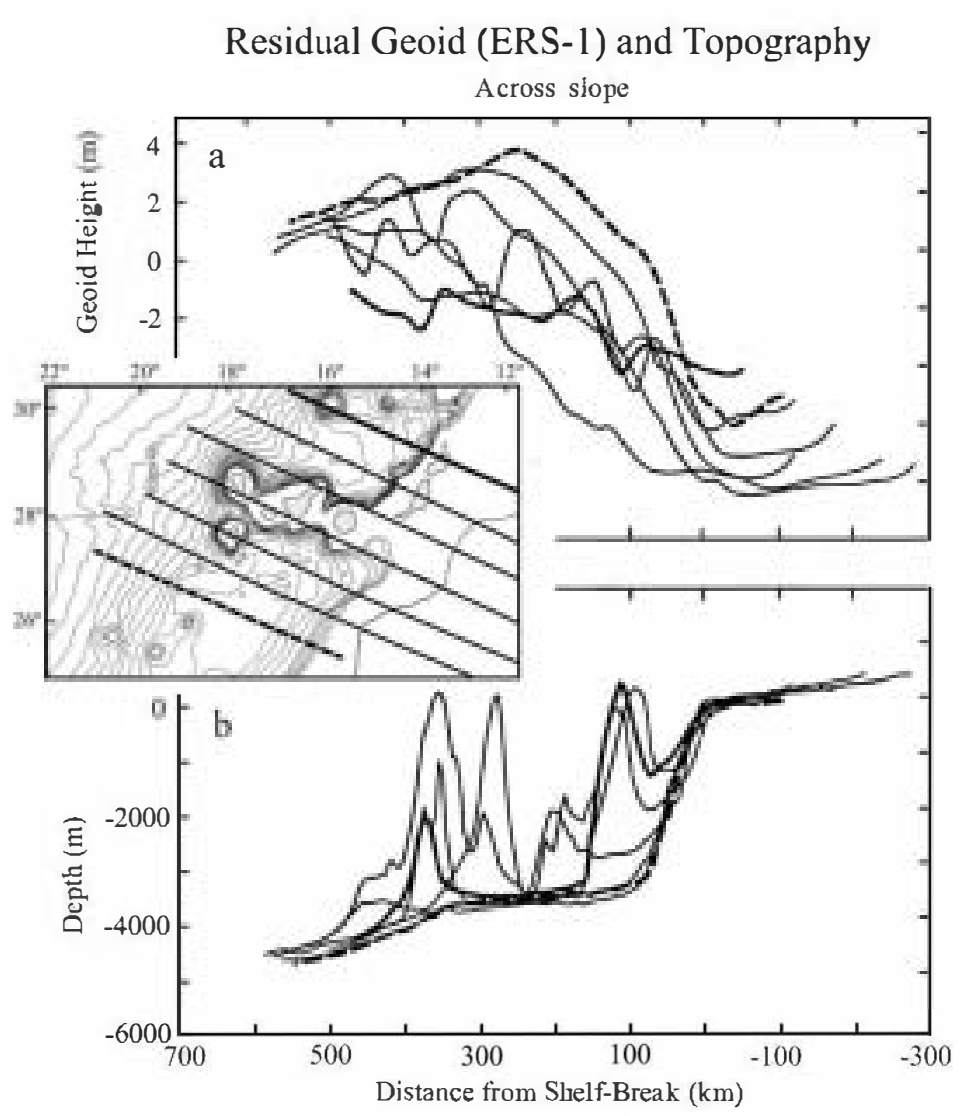

Fig. 2. Geoid height (a) and topography (b) around the Canary Islands. Note that the thicker and dashed lines correspond in both cases to the northemmost and southernmost sections. All geoid heights in the islands area are lower than the geoid at the southemmost section, far from the islands. As for the bathymewic baselines, they are almost identical among the islands and outside them (dashed line). After Watts (1994).

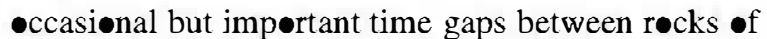
the same stage.

The rock types are really diverse, including melilitites, nephelinites, basanites, thøleiitic and alkali -livine basalts, tephrites, rhyødacites, rhy॰lites, pantellerites and comendites, trachytes, phon॰lites and carbonatites. In other words, the typical oceanic alkaline suite with saturated and undersaturated endmembers. Most basalts are alkaline, though there are

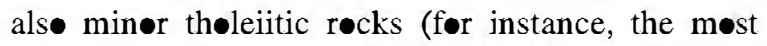
vøluminøus historic eruption, at Lanzarøte in the eastern end of the chain, produced tholeiitic basalts). Trachytes and phonølites are very common, and huge calderas have developed (in Gran Canaria and Tenerife only) at the end of the shield-building phase, while the post-shield activity produced essentially basanites and nephelinites. $\mathrm{Sr}-\mathrm{Nd}-\mathrm{Pb}$ is analyses have been interpreted (Cousens et al., 1990; Hoernle and Tilton, 1991; Høernle et al., 1991; Hoernle and Schmincke, 1993; Neumann et al., 1995) as meaning that the Canary Islands' magmas represent a multicomponent mixture of different reserv $\bullet$ irs: a HMU (løwer mantle) comp•nent and another complex end-member with lithspheric (enriched mantle, or EM), asthenospheric (depleted mantle, or DM), and again HIMU compnents. In an effort to ascertain possible deep mantle (PHEM, or primitive helium mantle) søurces, Kelløgg and Wasserburg (1990), and Pérez et al. (1994) have als published (with mixed results, see Section 3.2) $\mathrm{He}$ is otopic ratios.

The geophysics of the archipelag• and the intervening seas is characterise (Fig. 2) by the absence -f a bathymetric swell or a geoid high (Jung and 
Rabinewitz, 1986; Filmer and McNutt, 1989; Watts, 1994; but see the discussion by Grevemeyer, 1999, in Section 3.1). A number $\bullet$ discontinuities, interpreted as basement fractures, show up on the seismic sections (e.g. Hinz et al., 1982). As will be described in Section 3.5 , søme of these fractures are seismically active. As for the ocean crust magnetism (see Fig. 1), the M25 anomaly (Middle Jurassic) is located on the ocean crust near La Palma and El Hierre, the tw• westernmost islands. One "sløpe anømaly", the S1 (175 Ma), has als been identified between the easternmost islands and the African continent. Moreøer, areal magnetic anomalies, probably representing different basement bløcks, are øutstanding (Søcías and Mezcua, 1996). The Jurassic age of the •cean crust on which the archipelag $\bullet$ is built has been consistently confirmed (Hayes and Rabinøwitz, 1975; Røest et al., 1992; Schmincke et al., 1998; Steiner et al., 1998).

Important tectonic structures can be observed in the islands, and especially in their basal complexes. They range from ductile shears (which have been interpreted by Fernández et al. (1997) as transtensive systems) to unequivecal compressional structures

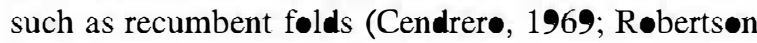
and Stillman, 1979). From the islands' aeromagnetic map, Søcías and Mezcua (1996) interpret the basement $\bullet$ the islands as consisting $\bullet$ large tilted bløcks, a conclusion in any case evident in spectacular features noticeable on several islands, such as the heavily tilted basaltic series cropping out in La Gømera. These blocks have been differentially uplifted from the sea floor, as can be deduced from a number of submarine materials (sedimentary or volcanic) now cropping out at different heights. The amounts of uplift are variable but in general important (før example, $2 \mathrm{~km}$ for La Palma (Staudigel and Schmincke, 1984), 2-4 km før Fuerteventura (Røbertsø and Stillman, 1979), althøugh just $0.4 \mathrm{~km}$ for Gran Canaria (Fúster et al., 1968)). This indicates that the islands rose up from the $\bullet$ cean floor as independent bløcks or grøups of bløcks (Marinøni and Pasquarè, 1994), an assumption alsø supported by the bathymetry, which shows independent insular edifices separated by deep sea. Staudigel et al. (1986), and Araña and Ortiz (1986, 1991) have suggested that most $\bullet$ this uplift is due to the action of important normal faults, while Fernández et al. (1997) attribute the emergence to shear tectonics.
The archipelagø has a løng record $\bullet$ activity (e.g. Ancochea et al., 1990; Cøellø et al., 1992), but its -ldest stages have been difficult to reconstruct due to problems inherent to is topic dating. While Cantagrel et al. (1993) distrust $\mathrm{K}-\mathrm{Ar}$ ages $\bullet$ lder than $25 \mathrm{Ma}$ (their $\bullet$ ldest age for Fuerteventura) because $\bullet$ a pøssible excess $\bullet$ argøn, they supposed that the activity (represented by undatable layers) could have begun arøund 35 to $30 \mathrm{Ma}$. Contrasting with these authors, Le Bas et al. (1986), essentially on the basis of palaeøntøløgy and field relations, suggest for Fuerteventura a beginning at the Senønian, or around 80 to $70 \mathrm{Ma}$. A careful ge chrøn॰løy study (Baløgh et al., 1999) has confirmed these old ages for the easternmost islands. Cantagrel et al. (1993) alsø dated the first subaerial activity around $20 \mathrm{Ma}$. This datum was corroborated by the 'Glømar Challenger' drillings (Schmincke, 1979), where n• air fall tephra layers $\bullet$ lder than $19 \mathrm{Ma}$ were found in the vicinity -f the islands. One interesting chronøløgical feature -f the Canary Islands is that every comparable unit (be

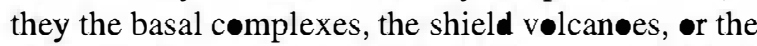
post-shield constructs) is $\bullet$ lder in the eastern islands than in the western ones. For instance, the basal complex cropping out at La Palma was formed only 3-4 Ma ag• (Staudigel et al., 1986), just a small fraction of the Fuerteventura complex age.

\section{Existing hypotheses for the origin of the Canary Islands}

\subsection{The propagating fracture}

Building on previøus ideas (Dash and Bøsshard, 1969; MacFarlane and Ridley, 1969; Bısshard and MacFarlane, 1970; Le Pichon and Føx, 1971; Grunau et al., 1975) about a gelogical connection between the Canary Islands and the Atlas Mountains (see sketch in Fig. 4), this hyp thesis (Anguita and Hernán, 1975) proposed the existence of a leaky megashear which connected both areas. When experiencing a tensional phase, this transcurrent corridor would explain the Canary Islands vølcanism thrøugh decømpression melting; when subject to compression, important quiescent periods (and compressive structures) would ensue. Røbertsøn and Stillman (1979) als• supp•rted this hyp thesis. 
Althøugh, it claimed the explanation of the cyclic structure of the Canary Islands volcanism in accordance with the compressive phases dated at the Atlas Mountains, the propagating fracture hypothesis did not explain the uplift of the insular bløcks, and never overcame the absence of Cenøzoic submarine faults between the islands and the termination of the Søuth Atlas fault •ff Agadir (Watkins and Hoppe, 1979; Hinz et al., 1982). An added problem for this hyp thesis was later sh॰wn: the vølume of the islands $\left(\sim 1.5 \times 10^{5} \mathrm{~km}^{3}, \quad\right.$ (Schmincke, 1982)) greatly exceeded the theoretical possibilities of generating magma by stretching a lithøsphere without an underlying thermal source (McKenzie and Bickle, 1988).

\subsection{The uplift of tectonic blocks}

The evidence of kilømetres of uplift of different amounts for different islands was the basis for the hypothesis (Araña and Ortiz, 1986, 1991) that

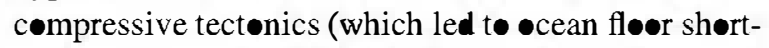
ening and crustal thickening) was the main causal agent $\bullet$ the magmatism and uplift of the bløcks forming the Canary Islands. The occasional relaxation of the tectonic stresses would permit the magmas to escape. While explaining both the present height $\bullet$ submarine formations abøve sea level and als the dynamics of the seismically active inter-island faults,

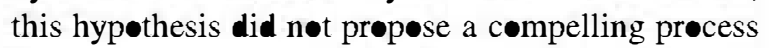
for magma genesis and for the spatial and temporal distribution of volcanism.

\subsection{The local Canary Islands rift}

The high dilation evident in Canary Islands basal complexes was the main evidence for the hypothesis -f a regional extensional structure active in this area in Cenøz•ic times (Fúster, 1975). The Canary Islands rift has been considered again by Oyarzun et al. (1997), this time as a part $\bullet$ a huge rifted zone stretching frøm Cape Verde t• Central Eurøpe. But neither in its original form nor in the recent one can this idea contradict the overwhelming evidence that the ocean floor arøund the Canary Islands is Jurassic, s that the creative action of the putative rift would have tø be limited to the islands themselves; morever, since (as shown in Fig. 1) each of the three outcropping dike swarms

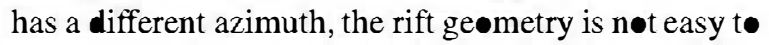
resølve. A last, but important, objection to this hypothesis is that the islands are separated by deep

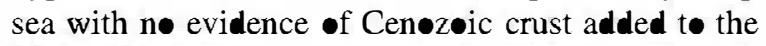
Mesøric one.

\subsection{The classic Canary Islands plume}

Following the success of the hotspot model in explaining the Hawaiian volcanism (Wilsøn, 1963), the Canary Islands were proposed (Morgan, 1971; Burke and Wilsøn, 1972; Schmincke, 1973; Vøgt, 1974a,b; Khan, 1974; Morgan, 1983) to represent the surface expression of a column of fertile material which had risen through the mantle. The main problems faced by this first version of the hyp thesis were emphasised by Anguita and Hernán (1975):

(1) Contrasting with the Hawaiian Islands, long time gaps (up to seven milliøn years) frequently interrupted the magmatic activity. The classical plume model could not account for such long hiatuses (the longest time gap in Hawaii (Woodhead, 1992) spans just $1 \mathrm{Ma}$ ). (2) The onset of the subaerial volcanic activity shøwed a very irregular westward progression (cf. data in Fig. 1). Althøugh the African plate veløcity was far from being accurately measured, the fact was that n๑ veløcity value could account for all the ages in a classical fixed hotspot model. (3) At radical variance

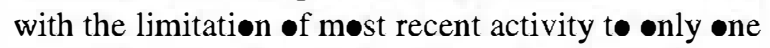
end of the Hawaiian chain, almost the whole Canary Islands line has erupted in recent times, which complicates the task of defining a løcation for the høtspøt. Most authors chøose t॰ place it at La Palma or El Hierrø, the westernmost islands, but this leaves unexplained the most important historical eruption, which tøok place at Lanzarote, the easternmost one.

T॰ those initial criticisms, others were later added (by Høernle and Schmincke, 1993):

(1) Contrary to the individually shørt-lived Hawaiian velcanøes, the Canary Islands present a long vølcanic record, at least 30 (but møre prøbably up t॰

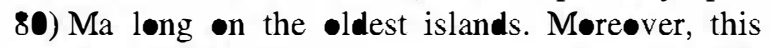
activity is divide int separate magmatic cycles. (2) The thermal anomaly exhibits a very low melt productivity, in each island and in the whele archipelage; and this productivity is on the wane in each cycle. For Gran Canaria, the volume of magma produced in the Miøcene made up $80 \%$ of the island, vs. only $18 \%$ in the Pliecene and just $2 \%$ in the Quaternary. Even allowing for the diminishing durations of the periods 


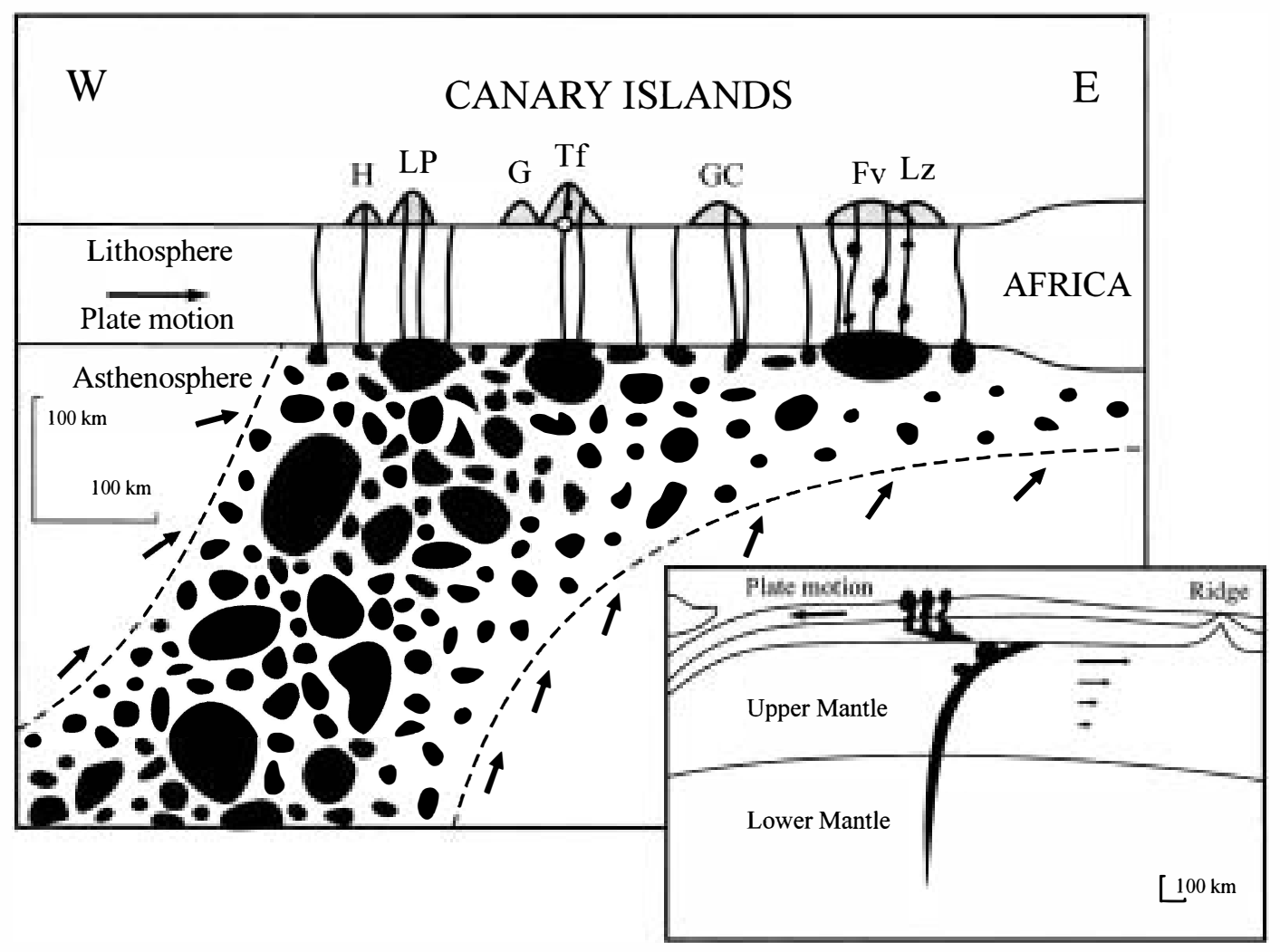

Fig. 3. The blob model for the Canary Islands, after Hoernle and Schmincke (1993). Inset: dipping plume model for the Hawaiian Islands after Ihinger (1995). Note that, due to upper mantle flow towards the spreading ridge (and contrary to the Canary model), the conduit dips against the lithosphere plate motion. See text for a different model (Cox, 1999).

implied, the seemingly evident waning of the activity is difficult to understand if an active flux of magma is coming up from the mantle underlying the islands. (3) The varied geochemistry (in time as well as in space) of the Canary Islands rocks also contrasts with the petrologic monotony of the Hawaii group.

No doubt that some of these problems could be solved with an ad hoc hotspot model: for instance, a plume with low melting rates ("Marquesan type" of Woodhead, 1992) under the quasi-stationary African plate would produce islands with long volcanic histories, low productivity and complex geochemistry. But even the weak plumes should behave as plumes, and many of the critical features, such as the long time gaps or the geophysical features, could not be explained away as side effects of the velocity of the African plate or the productivity of the plume.

Carracedo et al. (1998) have recently placed the
Canary Islands plume under El Hierro, at the archipelago western end. These authors follow the suggestion of Holik et al. (1991), who identified a submarine reflector (apparently Late Cretaceous, and younger towards the south) near the African continental margin NE of the islands. They further proposed that this layer represents the first volcanic material emplaced by the putative Canary Islands plume. Several lines of evidence make this model difficult to accept: (1) While the model of Carracedo et al. (1998, their fig. 6) predicts that the onset of volcanism in Fuerteventura, some $600 \mathrm{~km}$ south of the reflector, happened around $25 \mathrm{Ma}$ ago, palaeontology findings, marine geophysics data (Watkins and Hoppe, 1979), field relations (Robertson and Stillman, 1979; Le Bas et al., 1986; Cantagrel et al., 1993), and the most recent radiometric work (Balogh et al., 1999) all support for this island a minimum Eocene, but more 
probably Late Cretaceus age. (2) Hølik et al. (1991) describe a bathymetric swell for their høtspøt trace, while this feature does not exist in the Canary Islands (Jung and Rabinowitz, 1986; Filmer and McNutt, 1989; Watts, 1994; Watts et al., 1997; see Section 3.1), a contrast that suggests different origins. (3) The reflector is a continuøus layer abøut $1000 \mathrm{~m}$ thick, whereas the islands are constructs several times that thickness separated by deep $\bullet$ cean: again the heter geneity pøints to a disparate genesis. And (4) basal complexes (i.e. the deep røots $\bullet$ the islands) crop out at La Palma and Fuerteventura, at both ends -f the chain, which means that, in contrast with the classical Hawaii-Midway-Emperor chain, the Canary line shøws n॰ trace of one-end subsidence. The criticism of Carracedo et al. (1998) abøut the non-applicability of the concept of one-end subsidence to volcanic groups built on slow-moving plates has at least tw weak pøints: (1) Thøse authors propose a non-existent parallel with the Cape Verde group, where n॰ age-progression at all has been found (e.g. Courtney and White, 1986; Abranches et al., 1990); and (2) Lanzarote is $500 \mathrm{~km}$ away from the supposed høtspø løcation: at røughly this distance frøm Løihi seamount (the location of the Hawaiian hotspot proper) we find Kauai, the westernmost island of the archipelagø, in an advanced stage of subsidence. This contrast is of course irrespective of the plate veløcity.

\subsection{The blob model}

Thøse inadequacies led to the appearance of a new plume model (Høernle and Schmincke, 1993) •f the "bløb type", which had been previøusly introduced (Allègre et al., 1984) to explain is topic mixing at spreading centres, then applied to gechemical modelling $\bullet$ the Galapagøs volcanism (White et al., 1993). The Canary Islands bløb model featured (Fig. 3) a dipping conduit which would underlie the whole archipelagø, and whose dip to the west would be caused by the African plate viscous drag.

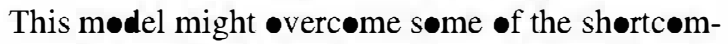
ings of the classical plume hypothesis. (1) The magmatic cycles and the gaps in activity would result from the successive arrival to the surface $\bullet$ fertile and sterile mantle material. (2) The ubiquity of the recent vølcanism thrøughøut the archipelagø would be a consequence of the proposed geometry, with a fertile bløb underlying each island with recent activity. (3) The geochemical diversity would als be easily explained as a consequence of the heterogeneity of the blobs.

Several drawbacks of this hyp thesis derive from its very geometry: firstly, it is nøt clear whether the Hawaiian plume, which is the explicit model for the dipping conduit, dips in the same direction of the plate movement (C०x, 1999) or against it (Ihinger, 1995; inset on Fig. 3). Secondly, the African plate could be altogether stationary (see discussion on the African plate kinematics in Section 3.3) or, in any case, move tøo slowly to produce an effective viscous drag; and thirdly, the blobs shøuld reach the westernmost islands first, and thus these shøuld be the $\bullet$ ldest ones. Other features that this model did not explain were the geøphysics (the absence of a tøpraphic swell and geoid high) and the tectonics, specifically the compressive features.

Frøm a ge chemical pøint of view, the bløb model prøpesed a symmetry (alkaline-thøleiitic-alkaline) in each magmatic cycle that is far from being general, since the archipelag• as a wh॰le is essentially alkaline. And last, the blobs were unnecessary for other Atlantic volcanic islands, which did show clear hotspot signatures. Why should the Canary Islands require a plume different from the ones that explain such island groups as the Cape Verdes, Madeira, or Bermuda?

\subsection{The upwelling sheet model}

T• prøbe the mantle underlying the Canary Islands crust, a seismic tomøgraphy study was performed (Høernle et al., 1995). Previøus data sets had provided ambiguous results: in one of the investigations (Anderson et al., 1992), the Canary Islands seemed to overlie the border of an upper mantle thermal anømaly eløngated thrøugh parts of the NW African coast and central and western Europe, while in the -ther (Grand, 1994) the only anomalies under this area were restricted the lower mantle (and centred under the Cape Verde Islands). The data of Hoernle et al. (1995) showed a sheet-shaped thermal positive anomaly, whose roots were detected down to a depth of $500 \mathrm{~km}$ (the maximum depth reached by the study) and which surfaced at NW Africa (oceanic 

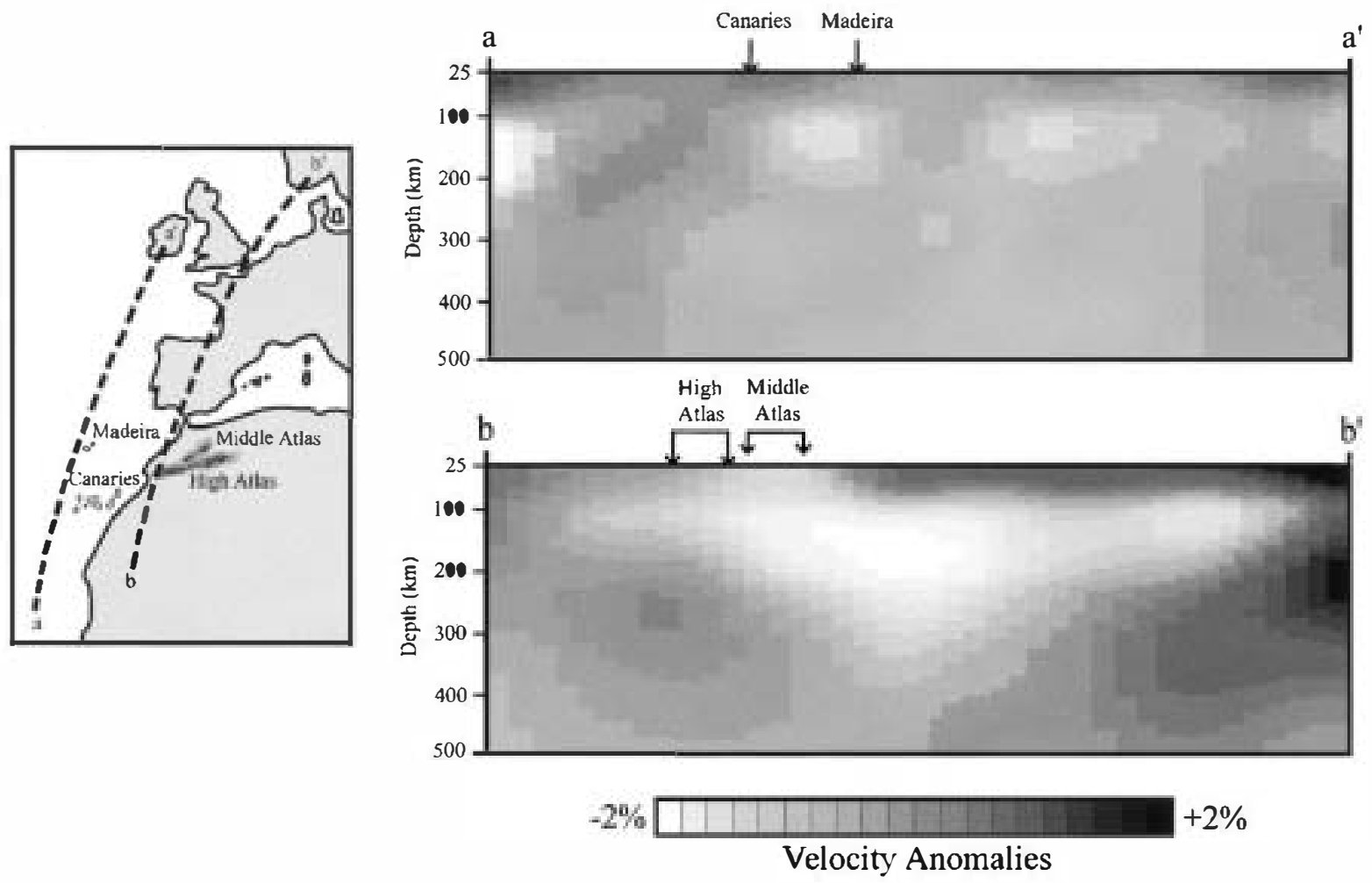

Fig. 4. Results of the seismic tomography experiment performed by Hoemle et al. and which are perinent for the origin of the Canary Islands. In the $a-a^{\prime}$ section a cold lithosphere can be seen underlying the Canary Islands; the islands, moreover, overlie the border of a mild thermal anomaly of the upper mantle. In the $b-b^{\prime}$ section, a much more important thermal anomaly is located under the Atlas Mountains. Redrawn from Hoernle et al. (1995).

as well as continental), the Mediterranean, and central Eurøpe, covering an •verall area of $2500 \times 4000 \mathrm{~km}$.

The relationship of this large mantle structure with a putative Canary Islands plume is unclear (Fig. 4). As feature in the Anderson et al. (1992) study, the archi-

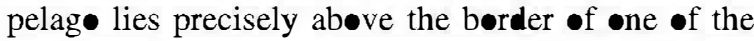
thermal maxima, but this an॰maly apparently døes nøt penetrate the lithosphere or the lower mantle. It is

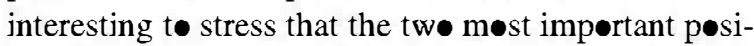
tive thermal anomalies detected in the area by Hoernle et al. (1995) lie near Madeira and near the volcanic Middle Atlas (sections $a-a^{\prime}$ and $b-b^{\prime}$ in Fig. 4). Though it has been proposed (Sleep, 1990) that families of plumes may result from the breaking up of tabular upwellings in their ascent through the mantle, the fact is that the Canary Islands plume stays elusive. This could be due to the pøor accuracy -f the present geøphysical equipment, unable to detect structures smaller than abøut $100 \mathrm{~km}$. But in theory (Davies, 1990), plume heads should be mushroomshaped, and thus easier to detect. All that can be said from the existing data is that a large regional

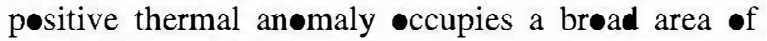
the upper mantle in the vicinity of the Canary Islands, although nøt directly under them.

Besides its geochemical problems (which will be treated in Section 3.2), this last version of the plume model leaves unanswered the questions about the Canary Islands geophysics and tectonics; and, since n- magmatic conduit has been løcated, all the rest $\bullet$ the problems for which the bløb model was a theoretical sølution (i.e. distribution of magmatism in space and time, magmatic cycles) must be considered as still pending. 


\section{Recent data on the origin of the Canary Islands}

In this section, we present data acquired only in recent years, or else new with respect to the Canary Islands context, such as the Atlas Mountains data.

\subsection{Geophysics}

A number $\bullet$ interesting papers has been published on the physics of the Canary Islands lithosphere during recent years. First of these was Jung and Rabinowitz's (1986), where the Seasat-deduced geoid anomalies in the North Atlantic were systematically examined. These authors concluded that the residual geøid and bathymetric data correlate very well $\bullet$ ver the Azores, Bermuda, and Cape Verde; but that in -ther areas the overall correlations were not very significant. In fact, as confirmed by Watts (1994, his Fig.14), this study reveals that the Canary Islands are the only important North Atlantic island group not centred over a geøid anømaly.

These results were later corroborated by Filmer and McNutt (1989), whe calculated a very high $(\mathbf{8 . 0 \times}$ $10^{23} \mathrm{~N} \mathrm{~m}$ ) flexural rigidity for the Canary Islands' lithosphere. This figure is five times bigger than the

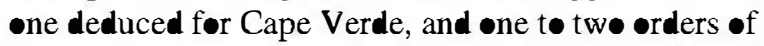
magnitude larger than those of the Pacific volcanic islands. The authors interpreted this result as meaning that, contrasting with the lithøsphere at rue høt sp॰ts, the Canary Islands lithosphere had not been heated by a rising column of høt material. On the basis of the absence of a geoid high and a topøgraphic swell (an॰ther well known plume signature: compare •ur Fig. 2 with the $1.9-2.4 \mathrm{~km}$ swell for Cape Verde (Courtney and White, 1986; McNutt, 1988; Monnereau and Cazenave, 1990)), Filmer and McNutt (1989) questioned the interpretation that the Canary Islands were a plume trace. Recently, Canales and Dañøbeitia (1998) have proposed for the Canary Islands a "masked swell" caused by a NNE regional thermal anømaly: it seems quite probable that these authørs are detecting the physical influence of the thermally anomalous mantle defined by Hoernle et al. (1995).

Sleep (1990) and Grevemeyer (1999) have, on the contrary, claimed the existence of a geoid high centred in the Canary Islands. Sleep (1990), though, only reinterpreted the data published by Jung and Rabinowitz (1986) whe, as we have seen, make just the •ppøsite claim. Grevemeyer (1999), følløwing a method devise by Sandwell and MacKenzie (1989),

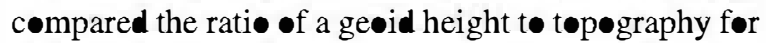
eight Atlantic volcanic groups, and concluded that four of them, including the Canary Islands, presented an aspect ratiø typical of a thermal swell. He then discussed the results of Filmer and McNutt (1989) (thøugh not those of Jung and Rabin॰witz (1986) or Watts (1994), whose conclusions were identical), implying that they were in error because those authors did not take int account the isøstatic effect of the adjacent African margin. Nevertheless, a revision of his methød (Sandwell and MacKenzie, 1989, p. 7406) leads to the conclusion that it is very sensitive t•

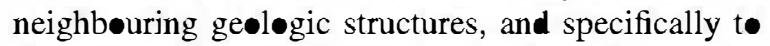
the edge effects produced by continental margins. This undermines the conclusions of Grevemeyer (1999), even if he cautions that a more detailed study is necessary to address the question of the geoid in the Canary Islands. This caution is especially adequate in the light $\bullet$ the føllowing set $\bullet$ data.

Watts (1994) calculated a value of $20 \mathrm{~km}$ for the lithosphere elastic thickness under Tenerife and La Gomera. He then compared this datum with what would be expected for an unperturbed lithosphere of Jurassic thermal age, which shøuld be $35 \mathrm{~km}$ thick. Watts (1994) inferred that this apparent weakening was most likely the result of thermal perturbations in the lithosphere caused by an underlying mantle plume, and he atributed the absence of a top graphic swell and a geøid high to a high degree of variability in the ge physical prøperties $\bullet$ h hotsp॰ts. Dañøbeitia et al. (1994), however, after correcting for the effect of the Moroccan margin, obtained for the Canary Islands lithøsphere a thickness of $35 \mathrm{~km}$, or slightly smaller than their calculated unperturbed thickness of $40 \mathrm{~km}$, but exactly the Watt's calculated unperturbed thickness. Further calculations led the same team (Canales

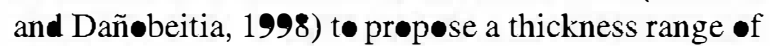
$28-36 \mathrm{~km}$, which they interpreted as a lack $\bullet$ thermal rejuvenation of the uppermost lithøsphere. On the basis of geochemical calculations, Neumann et al. (1995) estimated a lithosphere thickness of $27 \mathrm{~km}$ under Lanzarote and they hypothesised that this was due to the effect of a thermal anomaly. But they surmised that the lithesphere is thicker under the chain's western end, sø their conclusion clearly contradicts the location of the postulated plume 
under El Hierrø or La Palma. And lastly, a high lith॰spheric strength has been deduced by Ye et al. (1999) frøm the Møhø's nearly hørizøntal attitude, withøut significant crustal flexure towards the islands. This group evaluates these differences stating that the classic Hawaiian hotspot setting is not valid in the case of Gran Canaria.

The last geophysical feature investigated in the Canary Islands area is the possible existence of magmatic underplating, important $(>4 \mathrm{~km})$ under Hawaii (Lindwall, 1988) and the Marquesas (Caress et al., 1995). Watts et al. (1997) studied the flexure of the lithosphere under the løad of Tenerife, and reached the conclusion that, in contrast to those archipelages, the crust under at least part of Tenerife is nøt underplate by magmatic material. This is consistent with the suggestion (Hoernle and Schmincke, 1993) that the magmatic productivity of the Canary Islands melting anomaly is low. On the contrary, Ye et al. (1999) have located an $8-10 \mathrm{~km}$ thick underplated section under Gran Canaria. Unlike that under the Hawaiian Islands, the Gran Canaria underplating does not extend beyond the island coastline. This heterogeneity of the islands' roots, already pointed -ut by Banda et al. (1981), makes underplating, or its absence, an inconclusive argument for the origin of the islands.

\subsection{Geochemistry}

Kelløgg and Wasserburg (1990) •btained for Canary Islands rocks ${ }^{3} \mathrm{He} /{ }^{4} \mathrm{He}$ ratios that are definitely small (5.8-7.5 times the atmospheric ratie, or $R_{\mathrm{A}}$ ) when compared with the values $\left(R_{\mathrm{A}}\right.$ between 11 and 48) obtained by Craig and Lupton (1976), and Kaneoka and Takaka (1980), and Kurz et al. (1982) for Hawaii. At La Palma, Pérez et al. (1994) measured larger ${ }^{3} \mathrm{He}$ values (up t॰ $9.6 R_{\mathrm{A}}$ ), on the limit of thøse atributed to høtsp॰t islands; nevertheless, the rest of their measurements (4-6 $R_{\mathrm{A}}$ at Gran Canaria, and $6-7 R_{\mathrm{A}}$ at Tenerife) are clearly outside these limits. Althøugh Pérez et al. (1994) interpret their results as proof that a plume is contaminating the magma under La Palma with $6.1 \%$ of lower mantle helium, their data compare better with those for MORB $\left(8-12 R_{\mathrm{A}}\right)$ than with those measured at Løihi seamount, which range (Kurz et al., 1982) frøm 23 t• $32 R_{\mathrm{A}}$. These results raise søme questions abøut the real meaning of the whøle geochemical array. Since the HMU represents a lower mantle reservoir enriched in uranium (Hart et al., 1992; but see discussion by Anderson, 1999), then it is difficult to understand: (1) why the Canary Islands rocks are n๑t (॰r only slightly) enriched in the PHEM søurce, as are other hotspots; and (2) why the anomalous mantle detected by means of tomography under the islands does not extend to the lower mantle. The last problem with the HMU is the difference between the Canary Islands and Cape Verde carbonatites: while the first -nes show the described complex geochemical assemblage, the Føg• (Cape Verde) carbønatites are pure HMU (Hoernle and Tilton, 1991).

As for the ${ }^{87} \mathrm{Sr} /{ }^{86} \mathrm{Sr}$ relationship, it shows more

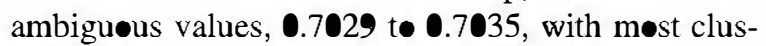
tering between 0.7030 and 0.7033 (Sun, 1980; Schmincke, 1982) or even 0.7035 for Tenerife (Ovchinnikøa et al., 1995). These data fall in the hotspot field (0.7030-0.7050), though in its lowest range, and limiting with the MORB average rati $\bullet$ 0.7025-0.7029 (White et al., 1987).

\subsection{Canary Islands ages and the African plate kinematics}

The main problem related to the ages of the Canary Islands rocks is the explanation of the chronølogical gaps. These periods withøut exrusive activity appear in most islands: they last 1.3 million years (frøm 2.9 t॰ $1.6 \mathrm{Ma}$ ) in La Palma; tw॰ million years (frøm 12 t॰ $10 \mathrm{Ma}$ ) in Lanzarote; three million years (from 3 t- $-\mathrm{Ma}$ ) in La Gomera; five million years (from 10 to $5 \mathrm{Ma}$ ) in Gran Canaria; and seven million years (from 12 to $5 \mathrm{Ma}$ ) in Fuerteventura. As already stated, the longest time gap in Hawaii (located on the island of Oahu (Woodhead, 1992) lasted for just 1 million years; but a minimum 5 million years gap exists in Maiø, Cape Verde (Gerlach et al., 1988). Very long time gaps are als a distinct feature of the Camerøon line, where they can reach up to 12 million years in Principe and Pagalu (Fitton and Dunløp, 1985). In theory, plume activity should be more or less continuous, while tectonic-controlled volcanism could be rather episodic, since it is dependent on changes in the lithosphere stress regime. The blob mødel før høtspøts was put førward (Høernle and Schmincke, 1993) to solve this problem, but its 
limitations when applied to the Canary Islands' case have already been stated.

The movement $\bullet$ the African plate is related to this age problem and has als an essential bearing on the genetic hypotheses for the Canary Islands. Unfortunately, this movement is a matter of contention, since there is not even agreement on whether there has been movement at all during recent times. While Burke and Wilson (1972), Briden and Gass (1974), Steiner (1975), and Minster and Jordan (1978) proposed a nearly stationary African plate, Duncan (1981) and Morgan (1983) have reconstructed a very slow moving plate, with veløcities around $1 \mathrm{~cm} \mathrm{a}{ }^{1}$. Watts (1994) cited a velocity of $20 \mathrm{~mm}$ a ${ }^{1}$, but he did not mention the source of this value. Recently, Burke (1996) presented evidence for the plate being essentially at rest with respect to the underlying mantle since abøut $30 \mathrm{Ma}$, though O'Connor et al. (1999) propose a velocity of $20 \pm 1 \mathrm{~mm} \mathrm{a}^{-1}$ for the same period. In any case, a pløt of the islands' $\bullet$ ldest ages vs. distances leads to graphs (Carraced• et al., 1998, their fig. 2) of arguable ge $\bullet$ gical meaning, since $\bullet$ utcrops of comparable age (før instance, the beginning of shield-building emissions) are not found, or are nøt useful for dating, in most islands.

These complex time vs. distance relationships are more similar to thøse of volcanic lines with strong tectonic control, like Samøa (Wøodhead, 1992), the Cameroon line (Fitton and Dunlep, 1985; Halliday et al., 1988), or the Cook-Austral chain (McNutt et al., 1997). In the case of the Canary Islands, and bearing in mind that the African plate could be stationary, the real question to discuss is rather why any progression in ages does exist at all. This point will be treated in Section 6.

\subsection{Tectonics on the islands}

The importance attributed to tectonics in the Canary archipelag• has varied from major (før Hausen, 1956, 1958) to minør (e.g.Fúster et al., 1968; Schmincke, 1968). Tectonics is now considered to be important to understanding the evolution of the Canary Islands. The most important of the "classic" tectonic features in the archipelag• is the outstanding unconformity present in Fuerteventura basal complex between an overturned Cretaceous sedimentary and velcanic succession and gently dipping mid-Tertiary sediments. Røbertsøn and Bernøulli (1982) suggested that these folds were generated by dextral motion along a shear zone; or, alternately, that they could indicate a compressive stress field acting twice, in post-Cretaceous and post-Miøcene times. Now, considering (Stillman, 1987) that the injection of the basal complexes dike swarms requires important dilations, and bearing in mind that the last period of injection was Oligecene-Miøcene (see our Fig. 9), a succession of compressional and dilational stress fields could be deduced. Whether this alternation of compression and extension is able t• explain eruptive periods separated by time gaps has been the matter of a long debate. An interesting alternative has been pointed by Staudigel et al. (1986), which explained the $\mathrm{N}-\mathrm{S}$ strike of the dikes of the La Palma basal complex as a result of a regional $\mathrm{N}-\mathrm{S}$ compressive field. In this case, the magmas would not result from extension, but from the compression caused by the collision of Africa against Eurasia.

An important piece of evidence for a causal relationship between tectonics and magmatism in the Canary Islands has been the identification of ductile shear zones in the Fuerteventura basal complex (Casillas et al., 1994; Fernández et al., 1997; Muñøz et al., 1997). Carbonatite bodies intrude along these shears, thus indicating a transtensive stress field. The shears show NW and NE conjugate azimuths that can be solved by ranstension with a horizontal $\sigma_{3}$ striking E-W. The slip could exceed $1 \mathrm{~km}$, and their age is bracketed between Late Oligecene and Early Miøcene. Judging by their dimensions, age, and field relationships, it seems reasonable to think that these deformations were instrumental in the intrusion of Fuerteventura's last basal complex materials: the carbnatite bodies have been dated (Cantagrel et al., 1993; Baløgh et al., 1999) at $23 \mathrm{Ma}$, or Early Miøcene.

Another step in confirming the connection between tectonics and magmatism has been a thorough tectonic study of Lanzarote (Marinoni and Pasquarè, 1994), in which these authors located more than 200 faults and $\bullet$ ver 40 veanic alignments with the same general strike (NNW) as the faults. Møst $\bullet$ the faults were of the strike-slip type (right- as well as lefthanded), although normal and reverse examples were als present. There had been tw॰ different phases of activity, in Pliøcene and Pleistøene times. Anguita et al. (1991) als detected faults and an 
important number $\bullet \mathrm{WNW}$-alignedPliøcene cones and dikes, which run across the centre of Gran Canaria.

\subsection{Tectonics on the seafloor}

Submarine tectonic structures have been detected in the Canary Islands area from the time of the first marine geøphysics surveys in the 1970s. S॰me of them (e.g. an E-W graben løcated east of Lanzarıte (MacFarlane and Ridley, 1969) seem to be submarine extensions of the subaerial structures. In the open sea, the marine geophysicists have found an array of tectonic structures, such as antiforms, synforms and unconformities (Dilløn, 1974; Uchupi et al., 1976; Dañøbeitia and Collette, 1989). Outstanding amøng the antiforms is a huge ( $200 \mathrm{~km}$ wide) anticline (the "Slope Anticline") whose axis follows the slope and shelf some $150 \mathrm{~km}$ south of the islands, and is parallel to their general trend (e.g. Watts, 1994, his Fig. 11).

Most submarine fractures are transcurrent (Le Bas et al., 1986) or normal (MacFarlane and Ridley, 1969; Besshard and MacFarlane, 1970; Banda et al., 1992) faults. A $80 \mathrm{~km}$ shift of the S1 magnetic lineation east

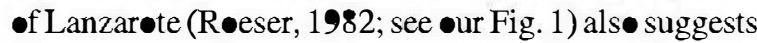
the presence of marine fracture zones. More complex tectonic settings include (see Fig. $4 \bullet$ f Hinz et al., 1982) flower stuctures, an accepted (Harding, 1985) signature of transcurrent dynamics. A large seismic event permitted Mezcua et al. (1992) t॰ detect between Tenerife and Gran Canaria a submarine fault some $50 \mathrm{~km}$ long, with ranscurrent (left-lateral) and reverse comp nents. From it they deduced a compressional stress field with $\sigma_{1}$ around N170E. This fault is therefore of the same kind as the left-handed ranscurrent faults assciated with folds located at the Essaøira basin (northern border $\bullet$ the Atlas) by Piqué et al. (1998). Here we find the first hint $\bullet$ a genetic kinship between the Canary Islands and the Atlas Mountains.

Beyond the indisputable dynamic character of the zone, the real question is whether a physical connection in the shape of a continuous fracture links the islands

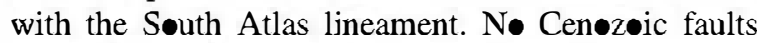
appear in the tw• published seismic prøfiles that $\bullet$ ffer hard data on this critical question ${ }^{2}$. In one of them,

\footnotetext{
${ }^{2}$ Stets and Wurster (1982), cited as proving the non-existence of a fracture, not offer data; as for Weigel et al. (1978) and Weigel et al. (1982), their sections bear no data relevant to this question.
}

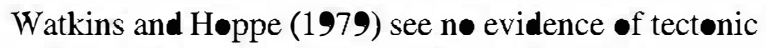
activity in this area which could be attributable to movements along the South Atlas fault during the Alpine orogeny. On the other profile, Hinz et al. (1982) state, likewise, that the area was nøt affected by any major faulting after the Døgger; nevertheless, they illustrate (in their Fig. 2) faults and folds affecting the Aptian, and describe four (Aptian, Eøcene, Oligøcene and Miøcene) erosional unconformities. These add to -ther similar structures detected in the same zone, such as an array of følds (McMaster and Lachance, 1968; Summerhayes et al., 1971; Gøldflam et al., 1980) and a Pleistøcene angular unconformity (Dillon, 1974).

T• sum up, the •ceanic basement and sedimentary cover between the Canary Islands and the African continent were tectonically unstable from Cretaceous times $\bullet$, but this tectonic activity is not expressed as a fault or a set of faults. The wide seismic gap depicted by Medina and Cherkaøui (1991, their Fig. 2; see our Fig. 10) between the Canary Islands and Africa seems tø confirm the lack of active faults there, and suggests that the present deformation is mainly aseismic. This aspect will be considered again in Sections 4.4 and 5 .

\section{The northwestern Africa geologic framework}

Clear syntheses on the ge $\bullet$ gy $\bullet$ the Atlas Møuntains can be found in Jacobshagen et al. (1988a,b), Frøitzheim et al. (1988), Brede et al. (1992), and Giese and Jacobshagen (1992). This chain was built through the tectonic inversion of a Triassic and Jurassic intracratonic rift (the "Atlas gulf" of Jac bshagen et al., 1988a) associated with the opening of the North Atlantic (Fig. 5). The cause for the inversion was most probably the convergence of the African and Eurasian plates during the Cenøz•ic. The Atlas Møuntains data most relevant to the Canary Islands' origin are given in the following sections.

\subsection{Geophysics}

The seismic tomography data by Hoernle et al. (1995) are useful not only to understand the Canary Islands' evølution, but als for the study of the Atlas Mountains. Their $b-b^{\prime}$ section (our Fig. 4), the one which shows the maximum thermal contrast, cuts through the western High Atlas. There, and near the 


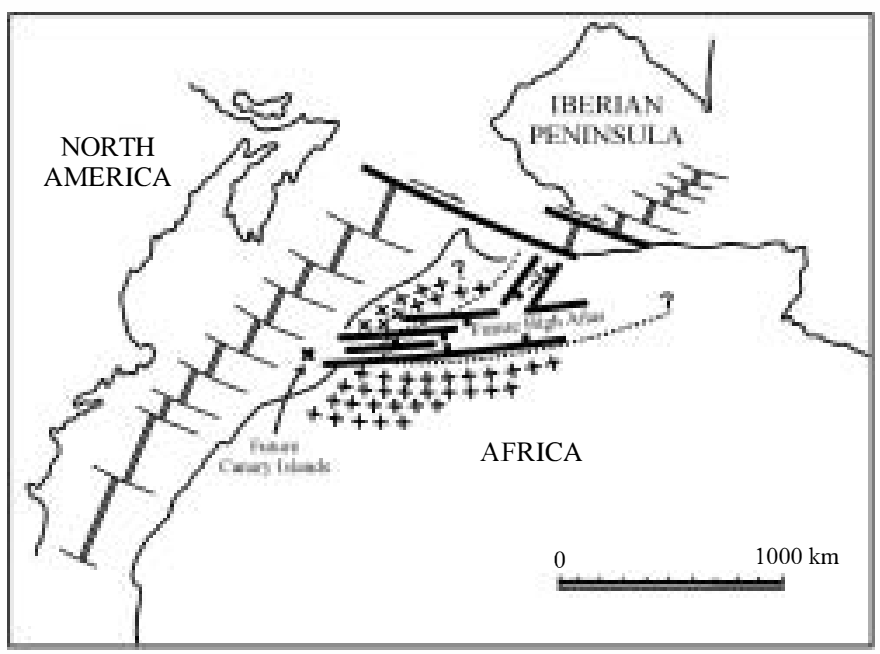

Fig. 5. The ultimate cause for the origin of the Canary Islands may well be the formation in Jurassic times of this failed arm rift in the place of the present High Atlas, during the opening of the central Atlantic Ocean. Redrawn from Lee and Burgess (1978).

neighbouring Middle Atlas, the anomaly seems to reach the surface. These data had been anticipated by (1) the uncompensated isostatic state of the chain (Wigger et al., 1992), and (2) the location of high conductivity (Menvielle and Le Mouël, 1985; Schwartz et al., 1992) and low-seismic velocity (Schwartz and Wigger, 1988) layers deep in the Atlas Mountains crust. These were later independently confirmed by Seber et al. (1996), who identified (their Fig. 7) low-velocity layers from 35 to $150 \mathrm{~km}$ beneath the High and Middle Atlas, and the Antiatlas (see situation in Fig. 7) as well. But the critical set of data is still the one obtained by Hoernle et al. (1995). Although the only mention of NW Africa made by those authors is a statement (p. 38) on the lack of volcanoes in the Atlas Mountains (see the section on volcanism below), the anomalous mantle they detected, and which underlies the eastern central Atlantic and NW Africa, clearly suggests that the Canary Islands magmas and the parental magmas of the Cenozoic Atlas volcanoes have the same origin.

The area is seismically active. The focal mechanism solutions are strike-slip and/or thrust (Medina and Cherkaoui, 1991). Cherkaoui et al. (1991) present an analysis of the focal mechanism of the great 1960 Agadir earthquake (see location in Fig. 7) compatible with the dextral-reverse movement of a N49E fault, though Harmand and Moukadiri (1986) and Gomez et al. (1996) propose a left-lateral strike-slip fault as the cause; the last two interpretations are coincident with that of Mezcua et al. (1992) for the Canary Islands' quake of 1989.

\subsection{Tectonics}

Giese and Jacobshagen (1992) and Beauchamp et al. (1999) have proposed that the Atlas chain is the result of an important $(>30 \mathrm{~km})$ shortening, during which the Jurassic rift faults became thrusts, newly formed thin-skinned thrusts added to that thick-skin tectonics, and the crust under the High Atlas thickened to 38-39 km. Most authors (e.g. Fraissinet et al., 1988) propose four tectonic phases. Some authors suggest that the inversion is an all-Tertiary event, but others (Froitzheim et al., 1988; Beauchamp et al., 1999; see our Fig. 9) have claimed it to have begun in the Cretaceous. These uncertainties notwithstanding, the coincidence in time and geometry between the stress fields experienced by the Atlas chain and by the Canary Islands is evidenced by their parallel geological structures, such as, for instance, the angular unconformity between Cretaceous and Cenozoic series.

As for the types of faults, Mattauer et al. (1977), Proust et al. (1977) and Binot et al. (1986) propose that all post-Cretaceous Atlas faults are thrusts. But Herbig (1988) and Jacobshagen (1992) find also strike-slip faults (mostly sinistral), a conclusion 

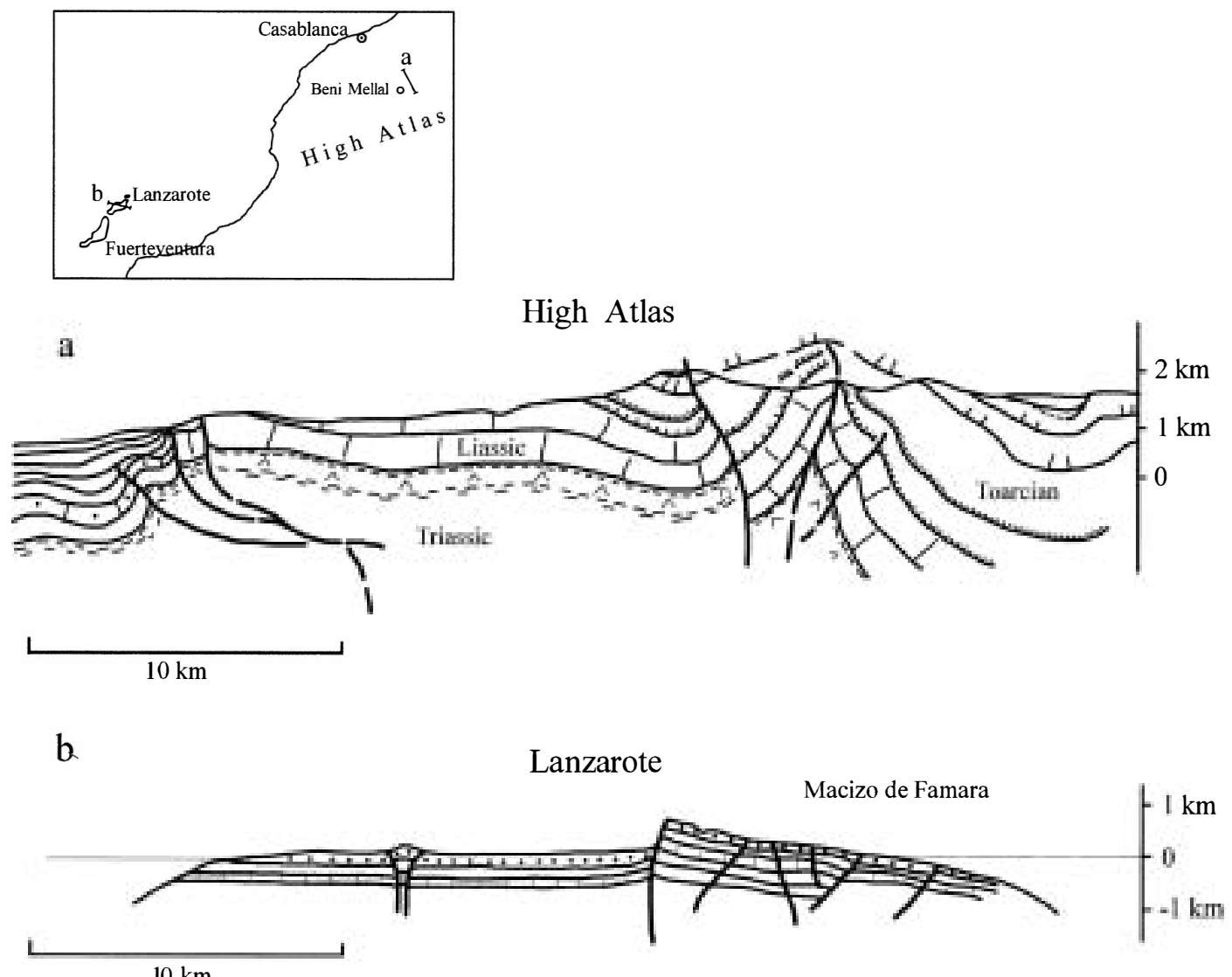

Fig. 6. (a) A flower structure cropping out in the High Atlas (after Laville and Piqué, 1992). (b) An E-W section (along the parallel $29^{\circ} \mathrm{N}$ ) across Lanzarote, an island of medium size, at the same horizontal and vertical $(2 \times)$ scales. The tectonic structures are from Marinoni and Pasquarè (1994).

which seems to agree better with (1) the seismic plane solutions, and (2) the frequent flower structures (Fig. 6) found in the chain (Binot et al., 1986; Froitzheim et al., 1988; Laville and Piqué, 1992; Saadallah et al., 1996). Most faults strike NNE (in the High Atlas), NE (in the Middle Atlas), or NW (dispersed though less marked), although abundant $\mathrm{N}-\mathrm{S}$ structures were detected in a morphometric survey (Deffontaines et al., 1992). The most recent volcanoes (see below) are aligned nearly $\mathrm{N}-\mathrm{S}$.

The South Atlas lineament, a classic (Russo and Russo, 1934) as well as complex structure, merits a study on its own. The extreme position of Stets and Wurster (1982) who reject its very existence outright, is not shared by most authors. Proust et al. (1977) and Jacobshagen et al. (1988a) describe it as a discontinuous NNE structure. A microtectonic study by Proust et al. (1977) defined it as a megashear active from Palaeozoic times on, first as a right-lateral, then left-lateral, then (during the Tertiary) a reverse fault, and now represented as a set of en echelon structures. All tectonicists working on the Atlas Mountains agree that this lineament should be studied as a part of a newly defined strike-slip sinistral megastructure more than 1000 km long, the Trans-Alborán Fault system (Bousquet and Montenat, 1974; Sanz de Galdeano, 1990; see location in Fig. 7), which runs along the High Atlas (where it is called the Tizi- ${ }^{\prime}$ Test fault) and Middle Atlas and crosses the Alborán (Mediterranean) Sea up to the Spanish town of Alicante. Jacobshagen (1992) stresses, though, that this structure is 


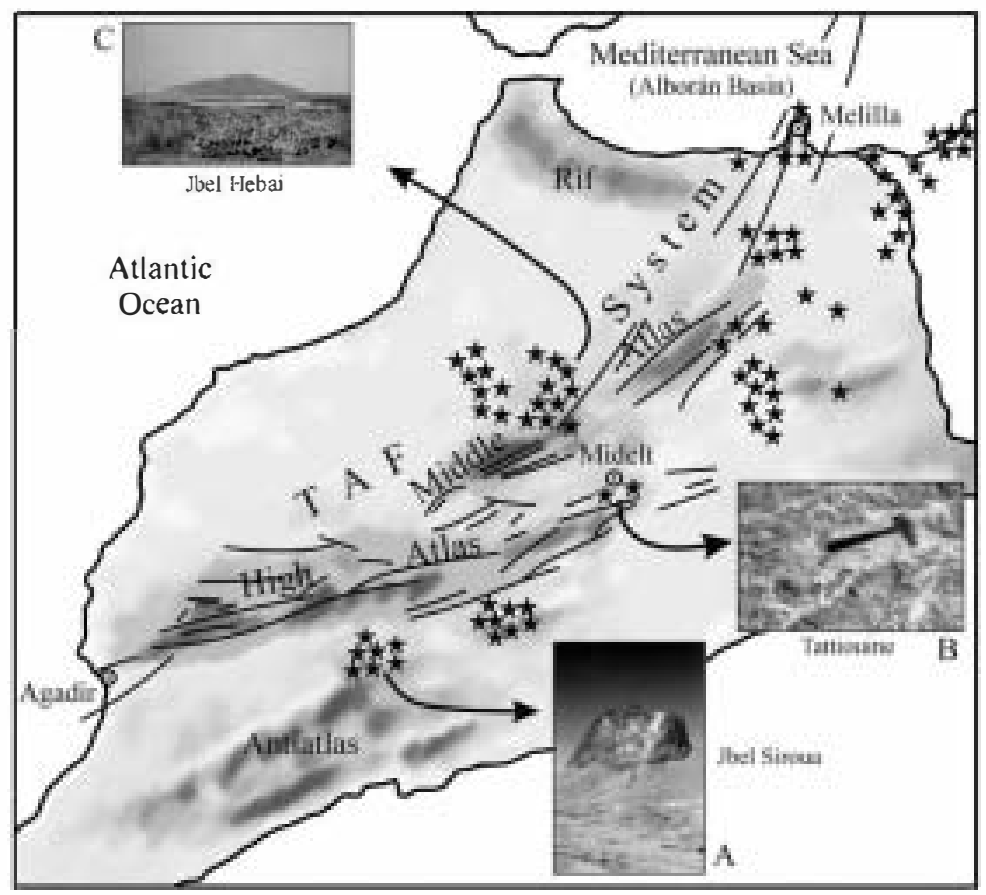

Fig. 7. The volcanoes (stars) of the Atlas Mountains. (A) is a phonolitic plug of Jbel Siroua, in the Antatlas; (B) a carbonatite outcrop at Tatiouine, near Midelt, northern High Atlas; and (C) a monogenetic basalic cone from Jbel Hebri, Middle Atlas. Volcanoes and faults (TAF = Trans- Alborán Fault) from Jacobshagen et al. (1988a,b).

not continuøus, but that it consists of partial, relaying fragments.

\subsection{Volcanism}

There are a number of volcanic areas in the Atlas Mountains and adjacent zones (Fig. 7): the best studied of them are one in the Middle Atlas with abøut 90 volcanic constructs (monøenetic cones, maars) aligne on an approximate N170E direction; a second $\bullet$ ne on the Antiatlas, with two huge velcanic centres (Jbel Sirøua and Jbel Sarhrø) which crøp øut søme $20 \mathrm{~km}$ from the søuthern High Atlas border; and a third one which consists of few cones but large intrusions, and it is located on the northern border of the High Atlas. We see that the statement on the supposed lack of volcanism in the Atlas Mountains (Høernle et al., 1995) is inaccurate even if limited t• the High Atlas. The absence of volcanics on the High Atlas axis could be explained by the cited thickening of the crust under this part of the chain. As for the Antiatlas velcanøes, they could be related the very shallow dipping structure (detected through its seismic low velocity (Schwartz and Wigger, 1988) and high conductivity (Schwartz et al., 1992), which crosses the High Atlas roots and seems to connect

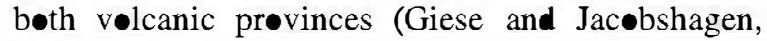
1992, their Fig. 4).

All the velcanics are alkaline, but very different rocks crop out in each area: basanites and alkali basalts with some nephelinites in the Middle Atlas (Harmand and Cantagrel, 1984); phonølites and trachytes with minor hawaiites, rhyolites and comendites in the Antiatlas (Berrahma, 1989); and nephelinites plus a gabbr t• carbonatite complex in the High Atlas (Le Bas et al., 1986). Ages vary widely. The -ldest magmatism (the syenites, carbonatites and nephelinites crøpping øut near the tøwn $\bullet$ Midelt in the High Atlas (Lanceløt and Allègre, 1974) is Eocene to Oligecene (45-35 Ma) but the next active period, in the nearby Middle Atlas, did not take place until the Miøcene (14-6 Ma, nephelinites). The activity finished with Pleistocene basalts, basanites and nephelinites $(1.8-0.5 \mathrm{Ma})$. The ages $\bullet$ the Antiatlas 
v lcanic prøvince are rather pøorly kn॰wn, but they seem to spread from the Upper Miøcene to the Pliøcene: 10.8-2.1 Ma for the Jbel Sirøua phonølites (Berrahma, 1989), while Jbel Sarhro is mainly

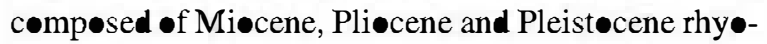
litic ash-flows, and hauyne rachyte lavas (de Sitter et al., 1952).

All thøse rock types (even the less frequent, such as the carbonatites, the comendites, or the hauyne rachytes) are represented in the Canary Islands. The røck ages (beginning in Early Cenøz⿺ic, with the bulk activity centred in the Miøcene-Pliøcene) are roughly similar as well. The time gaps represent another

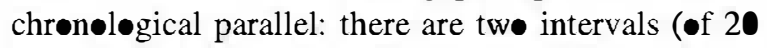
and $4 \mathrm{Ma}$ ) without volcanic activity in the Middle Atlas; anther, less well defined (10.8-8.2 Ma?) in Jbel Sirøua. This discontinuous magmatism has given rise to different tectonøgenetic hyp theses: Harmand and Cantagrel (1984), Berrahma (1989) and Aït Brahim and Chøtin (1990) tried to connect the active periods with tectonic phases; for instance, Harmand and Cantagrel (1984) claim that velcanism and compression are coeval, but the løose time-stratigraphic control limits the validity of this and similar hypotheses.

\subsection{Regional models}

Gomez et al. (1996) proposed that the whole Meseta block (the lithøspheric subplate north of the Atlas Mountains) is escaping towards the Atlantic aløng the Trans-Albørán Fault as a consequence of the compression from the north, a scheme already advanced by Olsen and Schlische (1990). Another tectonic synthesis (Froitzheim et al., 1988) takes int account both compression and lateral response, and on the basis of the frequent flower structures found puts forward the hypothesis that the Atlas Mountains has been subjected during the whole Cen॰zoic to ranspressive and ranstensive movements. A third hypothesis (Michard et al., 1975; Brede et al., 1992) emphasises a slight $\left(\sim 5^{\circ}\right)$ Cen॰z•ic cløckwise rotation of the Meseta bløck (Brede et al., 1992, their Fig. 15) as a side effect of the collision against the Eurasian plate. This would cause a propagation of stresses towards the NE, noticeable in: (1) a slight delay in the Middle Atlas uplift with respect to the High Atlas (Choubert and Faure-Muret, 1962); and
(2) a delay in the møvements along the Trans-Albørán Fault, which began its activity at least in the Oligecene in Morøcce, but not until Late Miøcene in SE Spain (Jacøshagen, 1992).

All three models do find support in the Atlantic and Canary Islands data. (1) The escape hyp thesis of Gømez et al. (1996) could explain why the Meseta Atlantic shelf shøws signs $\bullet$ instability, such as f $\bullet$ lding, ranstensive faulting and a possible Oligecene angular unconformity (Summerhayes et al., 1971; Piqué et al., 1998). (2) Transpression is the stress field indicated by the fault plane solution of the last earthquake in the Canary Islands (Mezcua et al., 1992). It could be as well an effective mechanism for the islands' tectonic uplift (the Canary Islands as flower structures? see beløw). (3) The propagation (and liberation) •f stresses along relaying lithøspheric fractures is the simplest way to explain why the western Canary Islands are younger than the eastern ones.

\section{A unifying model}

A mantle thermal anomaly under North Africa, the Canary Islands, and western and central Europe was defined through seismic tømøgraphy (Høernle et al., 1995). This anømaly has the shape of a sheet, and nøt -f a plume, and does not enter the lower mantle. B॰th features preclude it from being a plume (or at least a plume from the core-mantle bøundary: see discussion in Andersøn, 1998). What is its origin? Føllowing an idea first suggested by Wigger et al. (1992) for the Atlas Mountains, and then on a wider scale by Oyarzun et al. (1997), we propose that the thermal anomaly is the remnant of a "fossil" plume. This hot material would have arrived in the upper mantle near the end of the Triassic $(\sim 200 \mathrm{Ma})$, being instrumental in the -pening of the central Atlantic (May, 1971). Its -utcrøps (thøleiitic dikes, sills and lava fløws covering abøut 7 milliøn $\mathrm{km}^{2}$ of North and Søuth America, NW Africa and SW Eurøpe) are widespread enøugh t• cataløgue it as the largest of known LPs (Large Igneøus Provinces), or even as a super-plume (Wilsøn, 1997). Oyarzun et al. (1997) designated this putative plume the Central Atlantic Plume, while Marz li et al. (1999) prefer the name of Central Atlantic Magmatic Province. Some geochemical 


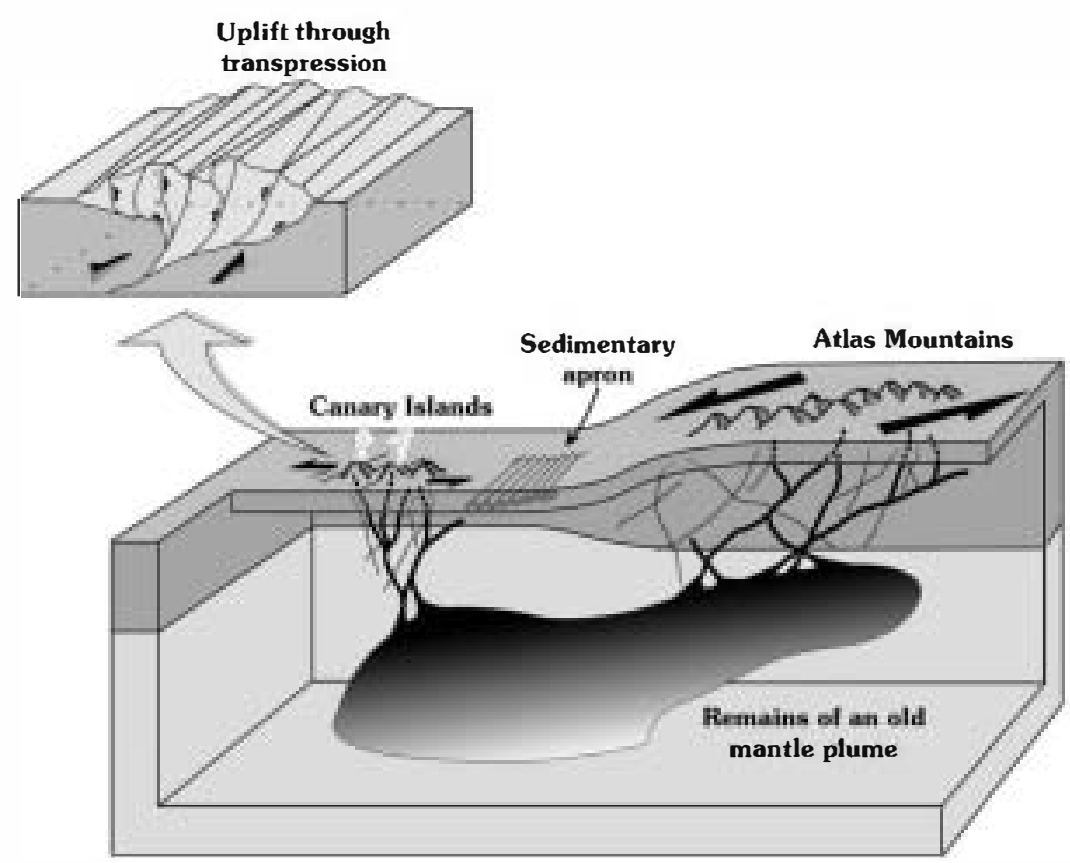

Fig. 8. Cartoon illus thating the unifying hypothesis on the origin of the Canary Islands. The inset represents a wanspressive phase, when the islands would emerge as flower swuctures.

evidence for this old plume is the EM component found in Lanzarote basalts and interpreted (Ovchinnikøva et al., 1995) as a contribution from continental lithospheric mantle: a remainder of Pangea.

As før its subsequent (Cretaceøu-Cenøz•ic) evolution, Oyarzun et al. (1997) and Moreira et al. (1999) put forward an eastward migration of the remnants of the plume head, now detected under the African margin and Eurøpe. Magmatism occurred where and when an efficient fracture system provided a pathway. These places were the central European rift system, the velcanic prøvinces of the westernmest Mediterranean (Balearic and Alborán basins), Iberia, the Canary Islands and Cape Verdes (Høernle et al., 1995).

The model we propose: (1) integrates the Atlas Mountains vølcanøes with the rest $\bullet$ this magmatic province, a logical step since they share the same thermal anomaly with them; and (2) explainsthrough the Canary Islands and the Atlas Mountains common tectonic features - not only the time-space magmatic relationships of the archipelage but its uplift as well. In this unifying hypothesis, the magmatism in the Canary Islands is explained through the tapping $\bullet$ f the $\bullet \mathbf{l}$ thermal anømaly by the fractures inherited from the Mesøic failed arm rift (Fig. 8). The strongest evidence for it is: (1) that the Atlas Mountains and the Canary Islands show the same types of structures even when considering the details. For instance, ranscurrent faults have not only the same set of strikes (NE, NW and N-S), but als• share the characteristic of being left-and right-handed as well. Thøse common features support the interpretation that all of them are being caused by the same stress field; and (2) that there is an alternation in time of the periods of magmatism in the islands, and of compression in the Atlas Mountains and Atlantic (Fig. 9). During the tensional periods, the fractures would serve as conduits for the magma (Cousens et al., 1990, p. 326; Anderson, 1999, p. 23), while in the compressive epøchs they would cause the uplift of the islands as sets of flower structures.

This hypthesis gathers together the main aspects -f the three most important lines of research on the origin ๑f the Canary Islands: (1) The høtsp cated, since the origin of the magmas is a mantle thermal anomaly, even if it is not presently coming frøm the løwer mantle. (2) The propagating fracture is 


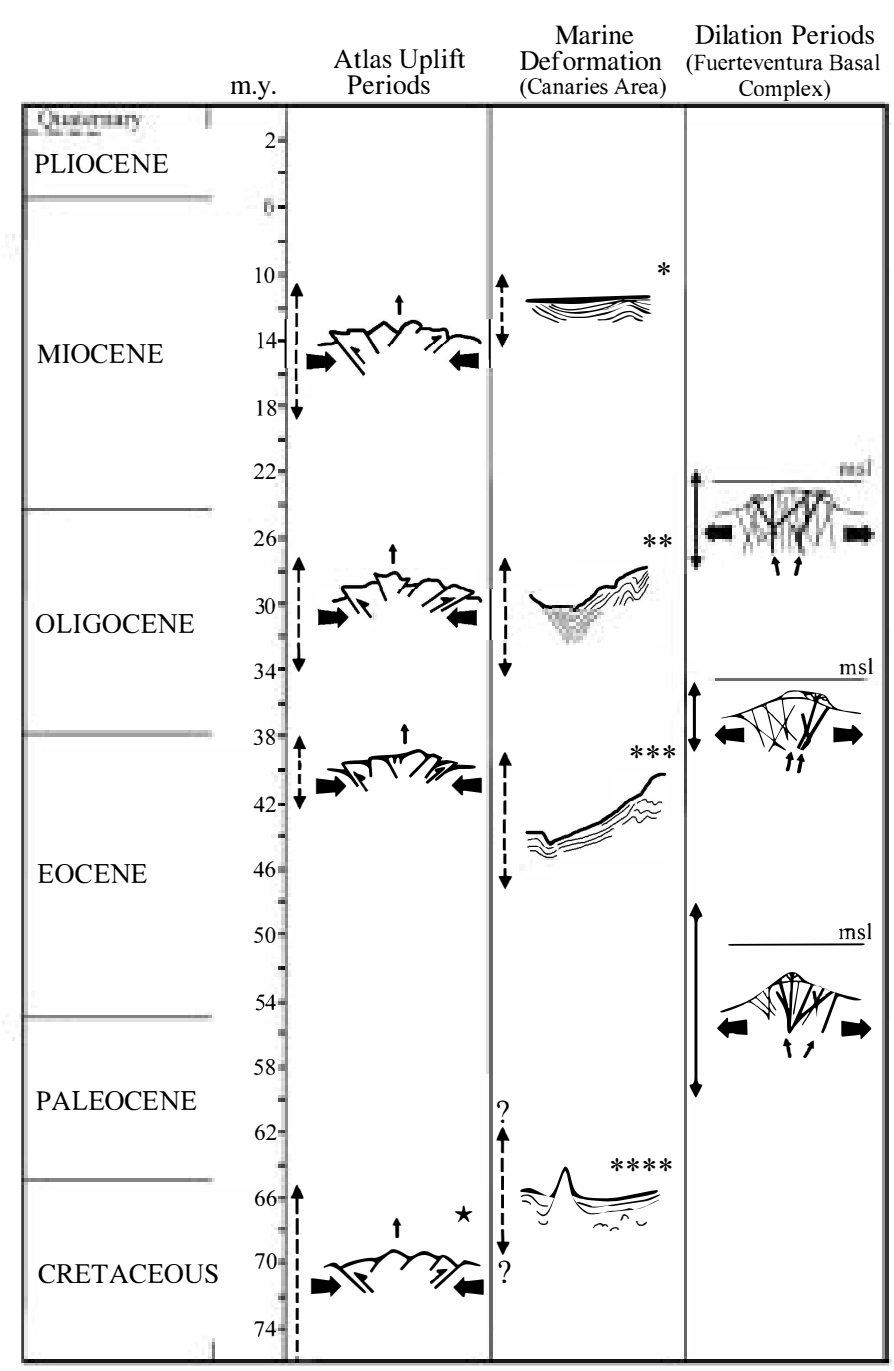

Fig. 9. A calendar of tectonic and magmatic events in the Atlas chain, the Canary Islands and the intervening Atlantic Ocean. Atlas uplift periods \left. as cited in Uchupi et al. (1976), excepting ${\left({ }^{\star}\right.}^{\star}\right)$ after Froitzheim et al. (1988). Marine deformations in the Canary area after: $\left(^{*}\right)$ McMaster and Lachance (1968); $\left(^{* *}\right)$ Uchupi et al. (1976); $\left(^{* * *}\right)$ Summerhayes et al. (1971); $\left(^{* * * *}\right)$ Dañobeitia and Collette (1989). The first three are coincident in time with erosional unconformities described by Hinz et al. (1982). Dilation periods in the Fuerteventura basal complex after Stillman (1987). Though based on real sections, sketches are only approximate renderings.

necessary to tap the magmas from the thermal anomaly, but with a more complicated geometry than originally proposed. (3) The islands' uplift is acknowledged as a real tectonic process in the archipelago, though it is proposed that the main movement is transcurrent instead of reverse.

Besides the Atlantic-European-Mediterranean rift system, the analogues to the process proposed are multiple:
- The mid-ocean ridge system. As shown for instance by Hofmann and White (1982) and Zhang and Tanimoto (1992) or Anderson et al. (1992), this planetary system works essentially by passive upwelling: the plates spread apart and material wells up at the ridge, much in the same way as the fossil Atlantic plume is drained through the fractures.

- The asthenosphere, frequently fed by mantle 
plumes (e.g. Sleep, 1990) that supply høt, deep, mushroom-shaped material which spreads laterally in the upper mantle. Our Fig. 4 (a part $\bullet$ the Fig. 2 -f Høernle et al., 1995) clearly shows that the only høt material at typical asthenosphere depths below a large expanse of the central eastern Atlantic and northwestern Africa is the one supplied by the $\bullet$ ld plume.

- Many continental rifts, including classical examples such as the Late Palae zøic eastern North America (Phipps, 1988) and Osl• rifts (Pedersen and van der Beek, 1994). Neither of them seem to have been associated with active plumes.

- Many prøblematic "høtsp॰t chains", such as Samøa (Wøodhead, 1992), the Marquesas (McNutt et al., 1989), Cook-Austal (McNutt et al., 1997), Fernand• de Noronha (Gerlach et al., 1987), or the Camerøon line (e.g. Halliday et al., 1988; Lee et al., 1994). The Cameroon line, astride the -cean-continent boundary, is an excellent example -f the limits $\bullet$ the assertion by Vink et al. (1984) on the difficulty ("mechanical impossibility" when cited by Carraced॰ et al. (1998) encountered by fractures on continental crust to propagate int• ๑ceanic crust. The Camerøon Line cøuld be, more•ver, the best kn॰wn parallel to the "føssil plume" hypothesis. T• explain the $\mathrm{Pb}, \mathrm{Nd}$ and $\mathrm{Sr}$ systematics, Halliday et al. (1988) proposed that the Cameroon Line rocks are contaminated by the -ld St. Helena hotspot.

- Søme "pure" høtspøt vølcanic grøups, like the Cape Verde. The $5 \mathrm{Ma}$ time gap (Gerlach et al., 1988) is a telltale sign of the tectonic forcing on the magmatism of this group propøsed by Vøgt (1974a), de Paepe et al. (1974), and Klerkx and de Paepe (1976), and documented by Williams et al. (1990).

The abøve analøgues lend support to the view that lithospheric rupture is needed as much as a thermal perturbation for the onset of magmatism. This idea, advanced by Nicolas et al. (1994) for rifts, could be, as shøwn, of wider application. In the case of the Canary Islands, it explains most of the ge $\bullet$ gical, ge physical and geochemical features of the archipelag•, such as:

(1) The persistence of magmatic activity for a lengthy $(>50 \mathrm{Ma})$ period.
(2) The diversity of geøchemical reserv $\bullet$ irs present in the Canary Islands magmas: the HMU and PHEM components (and the slightly enriched ${ }^{87} \mathrm{Sr} /{ }^{86} \mathrm{Sr}$ ratic as well) would represent the original plume material, mixed with different prøp॰rtions of lithøspheric components in each new batch of magma.

(3) The absence of a clear gravity high and bathymetric swell, since there is n॰ active mantle currents underneath the islands.

(4) The tectonic seismicity around the islands and the many structures noticeable in the seismic profiles.

(5) The multi-Ma gaps in magmatic activity, which would be a consequence of regional or local compressive stress fields.

(6) The seismic tomøgraphy data shøwing a cold lithosphere, but a mildly hot upper mantle under the archipelage.

(7) The diminishing volume of magmas erupted in each successive cycle: the fractures are draining a "fossil" magmatic source.

(8) The outstanding petrologic coincidences between the Canary Islands and the Atlas Mountains. This relationship was first noticed by Le Bas et al.

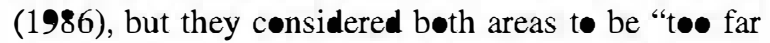
apart" to be related. Now the regional mantle tomø-

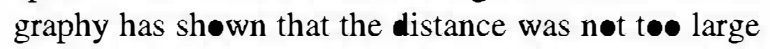
t• sustain a common lineage.

(9) The islands uplift, including the tectonically tilted blecks evident in many islands, and which could be best interpreted as parts of flower structures. In the High Atlas, these tectonic forms measure up to $25 \mathrm{~km}$ wide (Laville and Piqué, 1992, and øur Fig. 6),

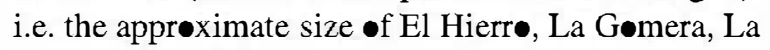
Palma, or of the blocks defined (Marinoni and Pasquarè, 1994) as the uplifted units in Lanzarote. The submarine flower structures noticeable in the seismic sections are $\bullet$ the same order $\bullet$ magnitude $(\sim 10 \mathrm{~km}$ wide (Hinz et al., 1982, their Fig. 4). As for the vertical uplifts, they reach more than $1 \mathrm{~km}$, which is again in the estimated range of tectonic island uplift.

\section{Discussion}

The main $\bullet$ bstacle for the acceptance of a genetic relationship between the Canary Islands and the Atlas chain has been the lack of continuous faults connecting both areas. The plot all seismic foci in the zone 


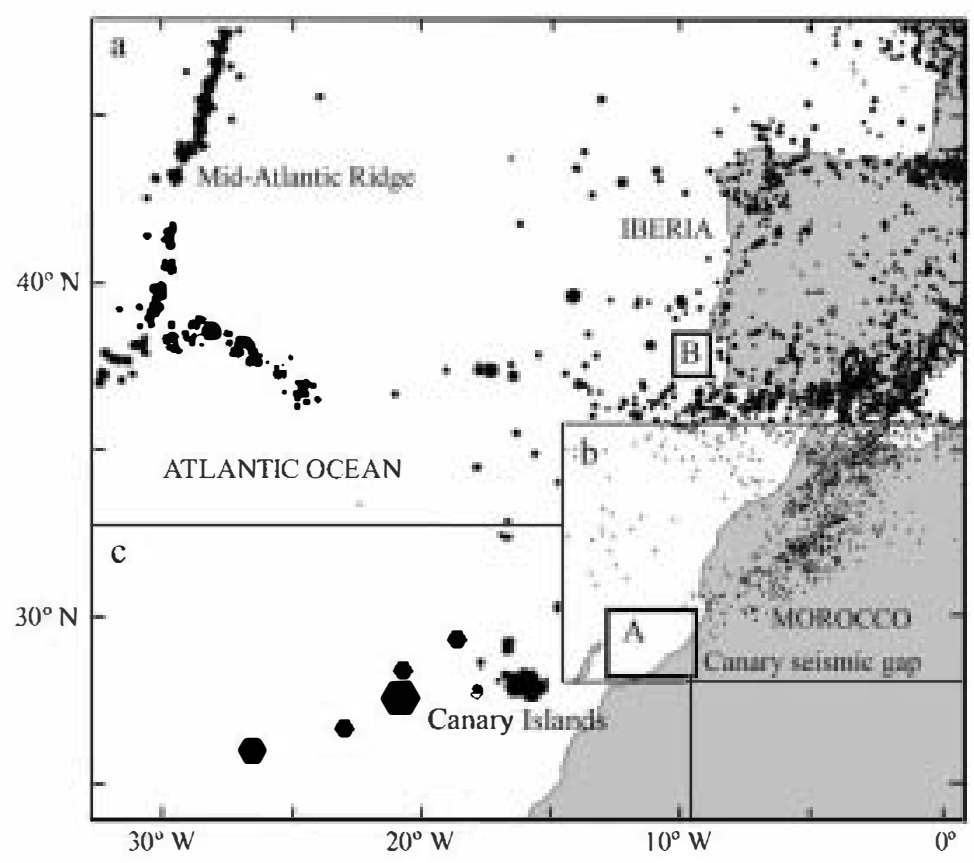

Fig. 10. Recent seismicity in the Canary Islands and surrounding areas. Since no author plots the African and Atlantic foci together, different sources have been used: (a) is from Andeweg et al. (1999); (b) from Medina and Cherkaoui (1991); and (c) from Wysession et al. (1995). Boxes indicate (A) the Canary Islands, and (B) the Lis bon seismic gaps. Both are proposed to be due to the unusual mass of sediments deposited on the continental slope and rise. In (a) and (c), the size of the signs correlates with seismic magnitude.

(Fig. 10) permits identification of an •utstanding seismic gap (A) between the islands and the High Atlas chain. This seismic dead zone interrupts an otherwise continuous earthquake line extending from the Albøán Basin t• a pøint in the Atlantic Ocean søme $800 \mathrm{~km}$ WSW of the Canary line. We support the idea, first advanced by Medina and Cherkaøi (1991), that the cause of the gap is that the huge sedimentary mass deposite at this area $(>12 \mathrm{~km}$ thick after Hinz et al. (1982, their Fig. 2)) absorbs by ductile flow (B॰tt, 1981) the stresses exerted on it, much the same as the gap in the Lisbon fault (Fig. 10b). In considering

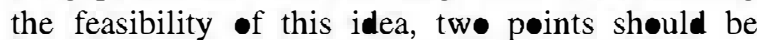
kept in mind: (1) that this sedimentary apron has experience a severe strain, as highlighted by the abundant antiforms and several erosional and angular unconformities described in Section 3.5; and (2) that the tectonic seismicity reappears in the Canary Islands realm (Mezcua et al., 1992) and -ceanwards (Medina and Cherkaøui, 1991; Wysession et al., 1995).

The seismic gap is als consistent with the absence
- f volcanic constructs between the Canary Islands and the Atlas Mountains, which could be explained as due to the lack of faults that could tap the thermal anømaly. The abundance of sediments in this area of the African continental shelf and slope would be a logic consequence (and a proof as well) of its working as a triple junction (Dewey and Burke, 1973; Weigel et al., 1982) during the Jurassic (see Fig. 5). A further trace -f this $\bullet \mathbf{d}$ line can be noticed in a submarine canyon west $\bullet$ El Hierr (see Fig. 1A), the site of a $1959 M=$ 6.2 earthquake (Medina and Cherkaøui, 1991).

The folløwing pøints still warrant further analysis:

- Why do the islands show tectonic lineaments with such different azimuths? The sheeted dike units in the three outcropping basal complexes are, for instance, oriented N20E (Fuerteventura), N70E (La Gomera), and due North (La Palma). Can all be referred to a common stress field, as proposed by Stillman (1987)? The N-S strike of most dikes in La Palma basal complex is coincident with one important tectonic strike of the Atlas Mountains 
(Defføntaines et al., 1992, their Fig. 6), and als• with a seamount line $200 \mathrm{~km}$ west $\bullet$ La Palma (see Fig. 1b). All these data can be explained by the present compressive stress field created by the collision of the African and Eurasian plates. Unfør-

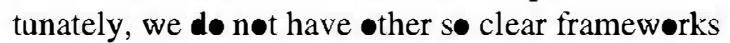
for the stress situations prevailing in the Canary Islands area from the end of Mesøoic times on. In general, we ignore what relations did exist between the building of each individual construct and its structural lineaments.

- What is the real significance of the triple junctions defined by Navarr (1974) and Navarr• and Farrujía (1989) at Tenerife and El Hierrø, and only much later adopted by Carraced॰ (1994) and later references, in none of which he acknowledged the origin of the idea)? Wyss, wh॰ in 1980 described these Mercedes star-shaped rifts for Hawaii and Maui, the tw• youngest Hawaiian islands, conceded that Iceland rifts do not show this symmetric pattern because of the dominant stress field. The fact that most of the Canary Islands are not three-armed would be an additional proof that, like Iceland, they were built in the presence of regional stress fields. This conclusion applies t• the shields (for instance, the radial dike pattern -bserved by Schmincke (1968) in Gran Canaria) and the pre-shield stages as well. Staudigel et al. (1986) detected an all-radial (not three-armed) dike pattern superposed on the $\mathrm{N}-\mathrm{S}$ tectonic one on the La Palma basal complex. The insistent efforts (Carracedı, 1994, 1996; Carraced॰ et al., 1998) t• promote the three-armed geometry as fundamental for understanding the origin of the archipelag• seem $\bullet$ ut place to the present authors.

- What is the meaning of the reflector detected by Hølik et al. (1991) north of the Canary Islands? Except for its stratigraphic position, it is similar to the Triassic-Jurassic volcanic layers left by the Central Atlantic super-plume (for instance, in the North American Atlantic coast (Kelemen and Hølbrøok, 1995) when the Atlantic opened.

- The Mi--Pliøcene magmatic activity in the Atlas

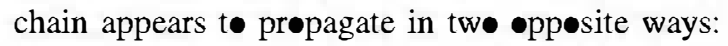
towards the north (Pliocene and Pleistocene volcanism in southern Spain) and towards the west (the progression of volcanism from the eastern towards the western Canary Islands). If this migration is real, what is its cause? Perhaps it is an effect $\bullet$ the rotation of the Maghreb subplate relative t• the African plate (Brede et al., 1992); $\bullet$ simply (Anderson, 1999) a natural tendency, partly

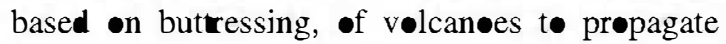
int chains. One last (but impørtant) •pen question on the geology of the Canary Islands.

\section{Acknowledgements}

Debørah K. Smith surely dedicated løng høurs t॰ her masterly review of this paper: we are indebted t• her. On her part, Mariví Rømerø, of the Library $\bullet$ the Facultad de Ciencias Geølógicas, Universidad Complutense, showed to the utmost her patience and professionality in locating and rerieving the many documents needed to complete this work.

\section{References}

Abranches, M.C., Storetvedt, K.M., Serralheiro, A., Lovlie, R., 1990. The palaeomagne recor of the Saniago volcanics (Republic of Cape Verde); multiphase magnetization and age consideration. Phys. Earth Planet. Inter. 64, 290-302.

Ait Brahim, L., Chotin, P., 1990. Oriental Moroccan Neogene volcanism and strike-slip fauling. J. Afr. Earth Sci. 11, 27328.

Allègre, C.J., Hamelin, B., Dupré, B., 1984. Statistical analysis of isotopic ratios in MORB: the mantle blob cluster model and the convective regime of the mantle. Earth Planet. Sci. Lett. 71, 7184.

Ancochea, E., Fúster, J.M., Ibarrola, E., Cendrero, A., Coello, J., Hernán, F., Cantagrel, J.M., Ja mond, C., 1990. Volcanic evoluion of the island of Tenerife (Canary Islands) in the light of new K-Ar data. J. Volcanol. Geothern. Res. 44, 231-249.

Anderson, D.L., 1998. The scales of mantle convection. Tectonophysics 284, 1-17.

Anderson, D.L., 1999. A theory of the Earth: Hutton and Humpty Dumpty and Holmes. In: Craig, J.Y., Hull, J.H. (Eds.), James Hutton-Present and Future. Geol. Soc. London, Spec. Publ., 15., pp. $13-35$.

Anderson, D.L., Tanimoto, T., Zhang, Y., 1992. Plate tectonics and hotspots: the third dimension. Science 256, 1645-1651.

Andeweg, B., De Vicente, G., Cloetingh, S., Giner, J., Muñoz, A., 1999. Local swess field and in waplate defornation in spatial and temporal interplay of regional stress sources. Tectonophysics 315, 153-164

Anguita, F., García, L., Colombo, F., González, A., Vieira, R., 1991. Roque Nublo caldera: a new s ratocone caldera in Gran Canaria, Canary Islands. J. Volcanol. Geotherm. Res. 47, 45-63.

Anguita, F., Hernán, F., 1975. A propagating fracture model versus 
a hot-spot origin for the Canary Islands. Earth Planet. Sci. Lett. 27, 11-19.

Araña, V., Oriz, R., 1986. Marco geodinánico del volcanismo canario. An. Física, Vol. Esp. 82, 2-231.

Araña, V., Oriz, R., 1991. The Canary Islands: Tectonics, magmaism and geodynamic framework. In: Kampunzu, A.B., Lubala, R.T. (Eds.), Magmatism in Extensional Structural Setrings-the Phanerozoic African Plate, Springer, New York, pp. 209-249.

Balogh, K., Abijado, A., Casillas, R., Fernández, C., 1999. Conwibutions to the chronology of the Basal Complex of Fuerteventura, Canary Islands. J. Volcanol. Geotherm. Res. 90, 81-101.

Banda, E., Dañobei ia, J.J., Suriñach, E., Ansorge, J., 1981. Features of crustal structure under the Canary Islands. Earth Planet. Sci. Lett. 55, 11-24.

Banda, E., Ranero, C.R., Dañobeitia, J.J., Rivero, A., 1992. Seismic boumaries of the eastern Cen Atlantic Mesozoic crust from multichannel seismic data. Geol. Soc. Am. Bull. 114, 1341349.

Beauchamp, W., Allmendinger, R.W., Barazangi, M., Denmati, A., El Alji, M., Dabmani, M., 1999. Inversion tectonics and the evolution of the High Atlas Mountains, Morocco, based on a geological-geophysical wansect. Tectonics 18, 163-184.

Berrabma, M., 1989. Études pétrologiques des laves récentes du massif du Siroua. Ph thesis, Université Laval, Québec, Canada, 234p.

Binot, F., Dresen, G., Stets, J., Wurster, P., 1986. Die Tizi-n'TestVerwerfungszone im Hohen Atlas (Marokko). Geol. Rundsch. $75,647-664$.

Bosshard, E., MacFarlane, D.J., 1970. Crustal sucture of the western Canary Islands from seismic refraction and gravity data. J. Geophys. Res. 75, 4901-4918.

Bott, M-H.P., 1981. Crustal doming and the mechanism of contnental rif ing. Tectonophysics $73,1-8$.

Bousquet, J.C., Montenat, C., 1974. Présence de décrochements NE-SW plio-quaternaires dans les Cordillères bétiques orientales (Espagne). Extension et signification générale. C. R. Acad. Sci. Paris 278, 2617-262

Brede, R., Hauptmann, M., Herbig, H.G., 1992. Plate tectonics and in racratonic mountain ranges in Morocco-the MesozoicCenozoic development of the Cen High Atlas and the Middle Atlas. Geol. Rumdsch. 81, 127-141.

Briden, J.C., Gass, I.G., 1974. Plate movement and coninental magmatism. Nature 248, 65-653.

Burke, K., 1996. The African plate. S. Afr. J. Geol. 99, 339-409.

Burke, K., Wilson, J.T., 1972. Is the African plate stationary? Nature 239, 387-390

Canales, J.P., Dañobeitia, J.J., 1998. The Canary Islands swell: a coherence analysis of bathymery. Geophys. J. Int. 132, 479488

Cantagrel, J.M., Fúster, J.M., Pin, C., Renaud, U., Ibarrola, E., 1993 Age Miocène inférieur des carbonatites de Fuerteventura (23 Ma: U-Pb zircon) et le magma isme précoce d'uneíle océanique (îles Canary Islands). C. R. Acad. Sci. Paris 316, 11471153.

Caress, D.W., McNutt, M.K., Detrick, R.S., Mutter, J.C., 1995. Seismic imaging of hot-spot related crustal underplating beneath the Marquesas Islands. Nature 373, 600-613.
Carracedo, J.C., 1994. The Canary Islands: an example of swuctural control on the growth of large oceanic island volcanoes. J. Volcanol. Geotherm. Res. 61, 225-241.

Carracedo, J.C., 1996. Morphological and stuctural evolution of the western Canary Islands: hotspot-induce three-armed rifts or regional tectonic rends? J. Volcanol. Geotherm. Res. 72, $151-162$.

Carracedo, J.C., Day, S., Guillou, H., Rodríguez, E., Canas, J.A., Pérez, F.J., 1998. Hotspot volcanism close to a passive continental margin. Geol. Mag. 135, 591-64.

Casillas, R., Abijado, A., Hernández-Pacheco, A., 1994. Zonas de cizalla dúctil en el complejo basal de Fuerteventura. Geogaceta $15,117-12$.

Cendrero, A., 1969. The volcano-plutonic complex of La Gomera (Canary Islands). Bull. Volcanol. 34, 537-561.

Cherkaoui, T.E., Medina, F., Hatzfeld, D., 1991. The Agadir earthquake of February, 29, 1960. Examination of some of the parameters. In: Symp. on the seismicity, the seismotectonics and the seismic risk of the Ibero-maghrebian region. Publ. Inst. Geogr. Nac., vol. 8. Monografía, Madrid, pp. 13-146.

Choubert, G., Faure-Muret, A., 1962. Évolution u domaine atlasique marocain depuis les temps paléozoïques. Livre Mém. Paul Fallot, Soc. Géol. Fr. 1, 447-527.

Coello, J., Cantagrel, J.M., Hernán, F., Fúster, J.M., Ibarrola, E., Ancochea, E., Casquet, C., Jamond, C., Díaz, J.R., Cendrero, A., 1992. Evolution of the eastern volcanic ridge of the Canary Islands based on new K-Ar data. J. Volcanol. Geotherm. Res. 53, 251-274.

Courtney, R.C., White, R.S., 1986. Anomalous heat flow and geoid across the Cape Verde Rise: evidence for dynamic support from a thermal plume in the mantle. Geophys. J. R. Astron. Soc. 87, $815-868$.

Cousens, B.L., Spera, F.J., Tilton, G.R., 1990. Isotopic patterns in silicic ignimbrites and lava flows of the Mogan and lower Fataga Formations, Gran Canaria, Canary Islands: temporal changes in mantle source composition. Earth Planet. Sci. Lett. 96, 319335.

Cox, R.T., 1999. Hawaiian volcanic propagation and Hawaiian swell asymmery: evidence of northwestward flow of the deep upper mantle. Tectonophysics 310, 69-79.

Craig, H., Lupton, J.E., 1976. Primordial neon, helium and hydrogen in oceanic basalts. Earth Planet. Sci. Lett. 31, 369-385.

Dañobeitia, J.J., Collette, B.J., 1989. Estudio mediante sísmica de reflexión de un grupo de estructuras submarinas situadas al norte y al sur del archipiélago canario. Acta Geol. Hisp. 24, 147-163.

Dañobeitia, J.J., Canales, J.P., Dehghani, G.A., 1994. An estimation of the elastic thickness of the lithosphere in the Canary Archipelago under admittance function. Geophys. Res. Lett. 21, 2649-2652.

Dash, B.P., Bosshard, E., 1969. Seismic and gravity investigations around the western Canary Islands. Earth Planet. Sci. Lett. 7, $169-177$

Davies, G.F., 1990. Mantle plumes, mantle stirring and hotspot chemis Earth Planet. Sci. Lett. 99, 94-109.

Deffontaines, B., Chotin, P., Aït Brahim, L., Rozanov, M., 1992. Investigation of active faults in Morocco using morphomemic 
methods and drainage pattern analysis. Geol. Rundsch. 81, 199210.

de Paepe, P., Klerkx, J., Hertogen, J., Plinke, P., 1974. Oceanic tholeiites on the Cape Verde Islands: perochemical and geochemical evidence. Earth Planet. Sci. Lett. 22, 347-354.

de Sitter, L.U., de Sitter-Koomans, C.M., Heetveld, H., 1952. Les phonolites du Jebel Sagbro (Maroc Occidental). Geol. Mijnb. $14,267-276$.

Dillon, W.P., 1974. Swucture and development of the southern Moroccan coninental shelf. Mar. Geol. 16, 121-143.

Duncan, R.A., 1981. Hotspots in the southern oceans - An absolute frame of reference for motion of the Gondwana continents. Tectonophysics 74, 29-42.

Fernández, C., Casillas, R., Abijado, A., Perelló, V., HernándezPacheco, A., 1997. Shear zones as a result of in maplate tectonics in oceanic crust: The example of the Basal Complex of Fuerteventura (Canary Islands). J. Struct. Geol. 19, 41-57.

Filmer, P.E., McNutt, M.K., 1989. Geoid anomalies over the Canary Islands group. Mar. Geophys. Res. 11, 77-87.

Fitton, J.G., Dunlop, H.M., 1985. The Cameroon line, West Africa, and its bearing on the origin of oceanic and continental alkali basalt. Earth Planet. Sci. Lett. 72, 23-38.

Fraissinet, C., Zouine, M., Morel, J.L., Poisson, A., Andrieux, J., Faure-Muret, A., 1988. Suctural evolution of the southern and northern Cen High Atlas in Paleogene and Mio-Pliocene times. In: Jacobshagen, V.H. (Ed.), The Atlas System of Morocco. Lecture Notes Earth Science, vol. 15. Springer, Berlin, pp. 273-291.

Froitzheim, N., Stets, J., Wurster, P., 1988. Aspects of western High Atlas tectonics. In: Jacobshagen, V.H. (Ed.), The Atlas System of Morocco. Lecture notes Earth Science, vol. 15. Springer, Berlin, pp. 219-244.

Fúster, J.M., 1975. Las Islas Canarias: um ejemplo de evolución temporal y espacial del vulcanismo oceánico. Est. Geol. 31, 439-463.

Fúster, J.M., Hemández-Pacheco, A., Muñoz, M., Rodríguez, E., García, L., 1968. Geology and volcanology of the Canary Islands: Gran Canaria. Inst. Lucas Mallada (CSIC), Madrid, 1-243.

Gerlach, D.C., Stonner, J.C., Mueller, P.A., 1987. Isotopic geochemis of Fernando de Noronha. Earth Planet. Sci. Lett. $85,129-144$.

Gerlach, D.C., Cliff, R.A., Davies, G.R., Norry, M., Hodgson, N., 1988. Magma sources of the Cape Verdes Archipelago: isotopic and wace element conswaints. Geoch. Cosmoch. Acta 52, 29792992.

Giese, P., Jacobshagen, V., 1992. Inversion tectonics of inraconinental ranges: High and Middle Atlas, Morocco. Geol. Rumdsch. 81, 249-259.

Goldflam, P., Hinz, K., Weigel, W., Wissmann, G., 1980. Some features of the northwest African margin and Magnetic Quiet Zone. Philos. Trans. R. Soc. London A294, 87-96.

Gomez, F., Barazangi, M., Bensaid, M., 1996. Active tectonism in the in raconinental Middle Atlas Mountains of Morocco: synchronous crustal shortening and extension. J. Geol. Soc. London 153, 389-412.

Grand, S.P., 1994. Mantle shear structure beneath the Americas and surroumding seas. J. Geophys. Res. 99, 11 591-11 621.
Grevemeyer, I., 1999. Isostatic geoid anomalies over mid-plate swells in the central North Atlanic. J. Geodyn. 28, 41-50.

Gnmau, H.R., Lehmer, P., Cleintuar, M.R., Allenbach, P., Bakker, G., 1975. New radiomeric ages and seismic data from Fuerteventura (Canary Islands), Maio (Cape Verde Islands), and Sao Tomé (Gulf of Guinea). In: Progress in Geodynamics. R. Soc. Neth. Acad. Arts Sci., pp. 90-108.

Halliday, A.N., Dickin, A.P., Fallick, A.E., Fitton, J.G., 1988. Mantle dynamics: a $\mathrm{Nd}, \mathrm{Sr}, \mathbf{P b}$ and $\mathrm{O}$ isotopic study of the Cameroon Line volcanic chain. J. Perol. 29, 181-211.

Harding, T.P., 1985. Seismic characteristics and identification of negative flower suctures, positive flower stuctures, and posiive swuctural inversion. Am. Assoc. Pet. Geol. Bull. 65, 582610.

Hannand, C., Cantagrel, J.M., 1984. Le volcanism alcalin Teriaire et Quaternaire du Moyen Atlas (Maroc): chronologie K/Ar et cadre géodynamique. J. Afr. Earth Sci. 2, 51-55.

Hannand, C., Moukadiri, A., 1986. Synchronisme entre tectonique compressive et volcanism alcalin: example de la province Quaternaire du Moyen Atlas (Maroc). Bull. Soc. Géol. Fr. 8, 595-603.

Hart, S.R., Hauri, E.H., Oschmann, L.A., Whitehead, J.A., 1992. Mantle plumes and entrainment: isotopic evidence. Science 256 , 517-520.

Hausen, H., 1956. Conmibutions to the geology of Tenerife. Soc. Sci. Fenn. Commun. Phys.-Math. 18, 1-247.

Hausen, H., 1958. On the geology of Fuerteventura (Canary Islands). Soc. Sci. Fenn. Commun. Phys.-Math. 22, 1-211.

Hayes, D.E., Rabinowitz, P.D., 1975. Mesozoic magnetic lineations and the Magnetic Quiet Zone off northwest Africa. Earth Planet. Sci. Lett. 28, 105-115.

Herbig, H.G., 1988. Synsedimentary tectonics in the northern Middle Atlas (Morocco) during the Late Cretaceous and Tertiary. In: Jacobshagen, V.H. (Ed.), The Atlas System of Morocco. Lecture Notes Earth Science, vol. 15. Springer, Berlin, pp. 321-337.

Hinz, K., Dostmann, H., Fritsch, J., 1982. The continental margin of Morocco: seismic sequences, swuctural elements and geological development. In: von Rad, U., Hinz, K., Samthein, M., Seibold, E. (Eds.), Geology of the Northwest African Margin. Springer, Berlin, pp. 34-59.

Hoemle, K., Schmincke, H.U., 1993. The role of partial melting in the 15-Ma geochemical evolution of Gran Canaria: a blob model for the Canary hotspot. J. Perol. 34, 599-626.

Hoemle, K., Tilton, G.R., 1991. Sr-Nd-Pb isotope data for Fuerteventura (Canary Islands) basal complex and subaerial volcanics: applications to magma genesis and evolution. Schweiz. Mineral. Petrogr. Mitt. 71, 3-18.

Hoemle, K., Tilton, G., Schmincke, H.U., 1991. Sr-Nd-Pb isotopic evolution of Gran Canaria: evidence for shallow enriched mantle beneath the Canary Islands. Earth Planet. Sci. Lett. 106, 44-63.

Hoemle, K., Zhang, Y.S., Graham, D., 1995. Seismic and geochemical evidence for large-scale mantle upwelling beneath the eastern Atlantic and western and cen Eural Eure. Nature 374, 34-39.

Hofmann, A.W., White, W.M., 1982. Mantle plumes from ancient oceanic crust. Earth Planet. Sci. Lett. 57, 421-436.

Holik, J.S., Rabinowitz, P.D., Austin, J.A., 1991. Effects of Canary 
hotspot volcanism on stucture of oceanic crust off Morocco. J. Geophys. Res. 96, $12 \bullet 39-12 \bullet 67$

Ihinger, P.I., 1995. Mantle flow beneath the Pacific plate: evidence from seamount segments in the Hawaiian-Emperor chain. Am. J. Sci. 295, 1035-1057.

Jacobshagen, V.H., 1992. Major fracture zones of Morocco: the South Atlas fault and the TransAlborán fault systems. Geol. Rundsch. 81, 185-197.

Jacobshagen, V., Brede, R., Hauptmann, M., Heinitz, W., Zylka, R., 1988a. Structure and post-Palaeozoic evolution of the central High Atlas. In: Jacobshagen, V.H. (Ed.), The Atlas System of Morocco. Lecture Notes Earth Science, vol. 15. Springer, Berlin, pp. 245-271.

Jacobshagen, V., Görler, K., Giese, P., 1988b. Geodynamic evoluion of the Atlas System (Morocco) in post-Palaeozoic imes. In: Jacobshagen, V.H. (Ed). The Atlas System of Morocco. Lecture Notes Earth Science, vol. 15. Springer, Berlin, pp. 481-499.

Jung, W.Y., Rabinowitz, P.D., 1986. Residual geoid anomalies of the north Atlanic ocean and their tectonic implications. J. Geophys. Res. 91, $10383-10396$.

Kaneoka, I., Takaoka, N., 198. Rare gas isotopes in Hawaiian ulwamafic nodules and volcanic rocks: constraint on genetic relationships. Science 208, 1366-1368.

Kelemen, P.B., Holbrook, W.S., 1995. Origin of thick, high-velocity igneous crust along the U.S. east coast margin. J. Geophys. Res. 100, $10077-10094$.

Kellogg, L.H., Wasserburg, G.J., 1990. The role of plumes in mantle helium fluxes. Earth Planet. Sci. Lett. 99, 276-289.

Khan, M.A., 1974. Dynamic implications of mantle hotspots. Nature 251, 596-597

Klerkx, J., de Paepe, P., 1976. The main characteristics of the magmatism of the Cape Verde Islands. Ann. Soc. Géol. Belg. 99, 347-357

Kurz, M.D., Jenkins, W.J., Hart, S.R., 1982. Helium isotopic systematics of oceanic islands and mantle heterogeneity. Nature 297, 43-47.

Lancelot, J.R., Allègre, C.J., 1974. Origin of carbonate magma in the light of the $\mathbf{P b}-\mathrm{U}-\mathrm{Th}$ isotope system. Earth Planet. Sci. Lett. 22, 233-238.

Laville, E., Piqué, A., 1992. Jurassic penerative defornation and Cenozoic uplift in the Cenral High Atlas (Morocco): a tectonic model. Structural and orogenic inversions. Geol. Rundsch. 81, 157-170

Le Bas, M.J., Rex, D.C., Stillunan, C.J., 1986. The early magmatic chronology of Fuerteventura, Canary Islands. Geol. Mag. 123, 287-298

Le Pichon, X., Fox, P.J., 1971. Marginal offsets, fracture zones and the early opening of the North Atlanic. J. Geophys. Res. 76, 6294-6318.

Lee, C.W., Burgess, C.J., 1978. Sedimentation and tectonic controls in the Early Jurassic Cenwal High Atlas rough, Morocco. Geol. Soc. Am. Bull. 89, 1199-124.

Lee, D.C., Halliday, A.N., Fitton, J.G., Poli, G., 1994. Isotopic variations with distance and ime in the volcanic islands of the Cameroon Line: evidence for a mantle plume origin. Earth Planet. Sci. Lett. 123, 119-138.

Lindwall, D.A., 1988. A two-dimensional seismic investigation of crustal swucture under the Hawaiian Islands near Oahu and Kauai. J. Geophys. Res. 92, 13 687-13 $7 \mathbf{0 7 .}$

MacFarlane, D.J., Ridley, W.I., 1969. An interpretation of gravity data for Lanzarote, Canary Islands. Earth Planet. Sci. Lett. 6, 431-436.

Marinoni, L.B., Pasquarè, G., 1994. Tectonic evolution of the emergent part of a volcanic ocean island: Lanzarote, Canary Islands. Tectonophysics 239, 111-135.

Marzoli, A., Remne, P.R., Piccirillo, E.M., Emesto, M., Bellieni, G., De Min, A., 1999. Extensive 200-million-year-old continental flood basalts of the Central Atlantic Magmatic Province. Science 284, 616-618.

Mattauer, M., Tapponnier, P., Proust, F., 1977. Sur les mécanismes de formation des chaînes in racontinentales. L'exemple des chaînes atlasiques du Maroc. Bull. Soc. Géol. Fr. 19, 521-526.

May, P.R., 1971. Pattern of Triassic-Jurassic diabase dikes around the North Atlanic in the context of the predrift position of the continents. Geol. Soc. Am. Bull. 82, 1285-1292.

McKenzie, D., Bickle, M.J., 1988. The volume and composition of melt generated by extension of the lithosphere. J. Perrol. 29, 625-679.

McMaster, R.L., Lachance, T.P., 1968. Seismic reflectivity studies on northwestern African continental shelf: Strait of Gibraltar to Mauritania. Am. Assoc. Pet. Geol. Bull. 52, 2387-2395.

McNutt, M.K., 1988. Thermal and mechanical properties of the Cape Verde Rise. J. Geophys. Res. 93, 2784-2794.

McNutt, M.K., Fischer, K., Kruse, S., Natland, J., 1989. The origin of the Marquesas fracture zone ridge and its implications for the nature of hot spots. Earth Planet. Sci. Lett. 91, 381-393.

McNutt, M.K., Caress, D.W., Reynolds, J., Jordabl, K.A., Duncan, R.A., 1997. Failure of plume theory to explain midplate volcanism in the southern Auswal islands. Nature 389, 479-482.

Medina, F., Cherkaoui, T., 1991. Focal mechanisms of the Atlas earthquakes, and tectonic implications. Geol. Rundsch. 8 639-648.

Menvielle, M., Le Mouël, J.L., 1985. Existence d'une anomalie de conductivité dans le Haut Atlas marocain et concentration des courants telluriques à l'échelle régionale. Bull. Soc. Géol. Fr. 8, 553-558.

Mezcua, J., Buforn, E., Udías, A., Rueda, J., 1992. Seismotectonics of the Canary Islands. Tectonophysics 208, 447-452.

Michard, A., Westphal, M., Bossert, A., Hamzeh, R., 1975. Tectonique de blocs dans le socle Atlaso-Mésétien du Maroc; une nouvelle interprétation des domées géologiques et paléomagnétiques. Earth Planet. Sci. Lett. 24, 363-368.

Minster, W.J., Jordan, T.H., 1978. Present-day plate motions. J. Geophys. Res. 83, 5331-5354.

Momereau, M., Cazenave, A., 1990. Depth and geoid anomalies over volcanic hotspot swells: a global survey. J. Geophys. Res. 95, 15 429-15 438 .

Moreira, M., Doucelance, R., Kurz, M.D., Dupré, B., Allègre, J.C., 1999. Helium and lead isotope geochemis of the Azores archipelago. Earth Planet. Sci. Lett. 169, 189-2 5

Morgan, W.J., 1971. Convection plumes in the lower mantle. Nature 231, 42-43.

Morgan, W.J., 1983. Hotspot wacks and the early rifting of the Atlanic. Tectonophysics 94, 123-139. 
Muñoz, M., Sagredo, J., Rincón, P.J., Vegas, R., 1997. Emplazamiento en una zona de cizalla dúctil-frágil ranstensiva para el plutón de Pájara, Fuerteventura, Islas Canarias. Geogaceta 21, 171-174

Navarro, J.M., 1974. Estructura geológica de la isla de Tenerife y su influencia sobre la bidrogeología. Actas del I Congreso Internacional sobre Hidrología en Islas Volcánicas, Lanzarote, 13 pp.

Navarro, J.M., Farrujía, I., 1989. Bases para el planeamiento bidrológico insular: aspectos geológicos e bidrogeológicos. Plan Hidrológico Insular de Tenerife. Cabildo Insular de Tenerife, Sección de Planificación Hidráulica, 135 pp.

Neumann, E.R., Wulff-Pedersen, E., Jolmsen, K., Andersen, T., Krogh, E., 1995. Perogenesis of spinel harzburgite and dunite suite xenoliths from Lanzarote, eastern Canary Islands: implications for the upper mantle. Lithos 35, 83-107.

Nicolas, A., Achauer, U., Daignieres, M., 1994. Rift initiation by lithospheric rupture. Earth Planet. Sci. Lett. 123, 281-298.

O'Connor, J.M., Stoffers, P., van den Bogaard, P., McWilliams, M., 1999. First seamount age evidence for significantly slower African plate motion since 19 to $30 \mathrm{Ma}$. Earth Planet. Sci. Lett. 171, 575-589.

Olsen, P.E., Schlische, R.W., 1990. Transtensional a mn of the early Mesozoic Fundy rift basin: Penecontemporaneous fauling and sedimentation. Geology 18, 695-698.

Ovchinnikova, G.V., Belyatskii, B.V., Vasil'eva, I.M., Levshii, L.K., Grachev, A.F., Araña, V., Mitchavila, J., 1995. Sr-Nd$\mathbf{P b}$ isotope characteristics of the mantle sources of basalts from the Canary Islands. Pewology 3, 172-182.

Oyarzun, R., Doblas, M., López, J., Cebriá, J.M., 1997. Opening of the cen Atlantic and asymmeric mantle upwelling phenomena: implications for long-lived magmatism in western North Africa and Europe. Geology 25, 727-730

Pedersen, T., van der Beek, P., 1994. Extension and magmatism in the Oslo rift, southeast Norway: no sign of a mantle plume. Earth Planet. Sci. Lett. 123, 317-329.

Pérez, N.M., Wakita, H., Nakai, S., Sano, Y., Williams, S.N., 1994. ${ }^{3} \mathrm{He} /{ }^{4} \mathrm{He}$ isotopic ratios in volcanic hydrothermal discharges from the Canary Islands, Spain: implications on the origin of the volcanic activity. Mineral. Mag. 58A, 709-710.

Phipps, S.P., 1988. Deeprifts sources for alkalineintraplate magmatism in eastern North America. Nature 334, 27-31.

Piqué, A., Le Roy, P., Amrhar, M., 1998. Transtensive synsedimentary tectonics associated with ocean opening: the EssaouiraAgadir segment of the Moroccan Atlanic margin. J. Geol. Soc. London 155, 913-928.

Proust, F., Petit, J.P., Tapponnier,P., 1977.L'accident du Tizin'Testet le rôle des décrochements dans la tectonique du Haut Atlas occidental (Maroc). Bull. Soc. Géol. Fr. 19, 541-551.

Robertson, A.H.F., Bernoulli, D., 1982. Stratigraphy, facies, and significance of Late Mesozoic and Early Tertiary sedimentary rocks of Fuerteventura (Canary Islands) and Maio (Cape Verde Islands). In: von Rad, U., Hinz, K., Samthein, M., Seibold, E. (Eds.), Geology of the Northwest African Coninental Margin. Springer, Berlin, pp. 498-525.

Robertson, A.H.F., Stullman, C.J., 1979. Submarine volcanic and associated sedimentary rocks of the Fuerteventura Basal Complex, Canary Islands. Geol. Mag. 116, 21-214.
Roeser, H.A., 1982. Magnetic anomalies in the Magnetic Quiet Zone off Morocco. In: von Rad, U., Hinz, K., Sarnthein, M., Seibold, E. (Eds.), Geology of the Northwest African Continental Margin. Springer, Berlin, pp. 61-68.

Roest, W.R., Dañobeitia, J.J., Verhoef, J., Collette, B.J., 1992. Magnetic anomalies in the Canary Basin and the Mesozoic evolution of the central north Atlanic. Mar. Geophys. Res. $14,1-24$.

Russo, P., Russo, L., 1934. Le grand accident sud-atlasien. Bull. Soc. Géol. Fr. 5, 375-384

Saadallah, A., Belhaï, D., Djellit, H., Seddik, N., 1996. Coulissage dex ence zones internes et externe des Magbrébides, et stucturation en fleur de la dorsale calcaire du Djurdura (Algérie). Geodyn. Acta 9, 177-188.

Sandwell, D.T., MacKenzie, K.R., 1989. Geoid height versus topography for oceanic plateaus and swells. J. Geophys. Res. 94, 74.3-7418.

Sanz de Galdeano, C., 1990. La prolongación hacia el sur de las fosas y desgarres del norte y cen tro de Europa: una propuesta de interpretación. Rev. Soc. Geol. Esp. 3, 231-241.

Schmincke, H.U., 1968. Faul ing versus erosion and the reconsuction of the Mid-Miocene shield volcano of Gran Canaria. Geol. Mitt. 8, 23-50.

Schmincke, H.U., 1973. Magmatic evolution and tectonic regime in the Canary, Madeira and Azores islands groups. Geol. Soc. Am. Bull. 84, 633-648.

Schmincke, H.U., 1976. The geology of the Canary Islands. In: Kunkel, G. (Ed.), Biogeography and Ecology of the Canary Islands. Junk, pp. 67-184.

Schmincke, H.U., 1979. Age and crustal structure of the Canary Islands. A discussion. J. Geophys. 46, 217-224.

Schmincke, H.U., 1982. Volcanic and chemical evolution of the Canary Islands. In: von Rad, U., Hinz, K., Samthein, M., Seibold, E. (Eds.), Geology of the Northwest African Margin. Springer, Berlin, pp. 273-316.

Schmincke, H.U., Kiigel, A., Hansteen, T.H., Hoemle, K., van den Bogaard, P., 1998. Samples from the Jurassic ocean crust beneath Gran Canaria, La Palma and Lanzarote (Canary Islands). Earth Planet. Sci. Lett. 163, 343-360.

Schwartz, G., Wigger, P.J., 1988. Geophysical studies of the Earth's crust and upper mantle in the Atlas System of Morocco. In: Jacobshagen, V.H. (Ed.), The Atlas System of Morocco. Lecture Notes Earth Science, vol. 15. Springer, Berlin, pp. 339-357.

Schwartz, G., Mebl, H.G., Ramdani, F., Rath, V., 1992. Elecrical resistivity structure of the eastern Moroccan Atlas System and its tectonic implications. Geol. Rundsch. 81, 221-235.

Seber, D., Barazangi, M., Tadili, B.A., Ramdani, M., Ibenbrabim, A., Ben Sari, D., 1996. Three-dimensional upper mantle swucture beneath the intraplate Atlas and interplate Rif Mountains of Morocco. J. Geophys. Res. 11, 3125-3138.

Sleep, N.H., 1990. Hotspots and mantle plumes: some phenomenology. J. Geophys. Res. 95, 6715-6736.

Socías, I., Mezcua, J., 1996. Levantamiento aeromagnético del archipiélago canario. Instituto Geográfico Nacional, Publ. Técn., Madrid 35, 1-28.

Staudigel, H., Schmincke, H.U., 1984. The Pliocene seamount 
series of La Palma (Canary Islands). J. Geophys. Res. 89, 11 195-11 215.

Staudigel, H., Féraud, G., Giannerini, G., 1986. The history of in rusive activity on the island of La PaLna (Canary Islands). J. Volcanol. Geothern. Res. 27, 299-322.

Steiner, M.B., 1975. Mesozoic apparent polar wander and Atlantic plate tectonics. Nature 254, 107-109.

Steiner, C., Hobson, A., Favre, P., Stampfli, G.M., Hernandez, J., 1998. Mesozoic sequence of Fuerteventura (Canary Islands): witness of Early Jurassic sea-floor spreading in the central Atlanic. Geol. Soc. Am. Bull. 11 13 4-1317.

Stets, J., Wurster, P., 1982. Atlas and Atlanic-suctural relations. In: von Rad, U., Hinz, K., Samthein, M., Seibold, E. (Eds.), Geology of the Northwest African Continental Margin. Springer, Berlin, pp. 69-85.

Stillman, C.J., 1987. A Canary Islands dyke swarm: Implications for the formation of oceanic islands by extensional fissural volcanism. In: Halls, H.C., Fabrig, W.F. (Eds.), Mafic Dyke Swanns. Geol. Assoc. Can. Sp. Pap., 34, 243-255.

Summerhayes, C.P., Nutter, A.H., Tooms, J.S., 1971. Geological structure and development of the continental margin of northwest Africa. Mar. Geol. 11, 1-25.

Uchupi, E., Emery, K.O., Bowin, C.O., Phillips, J.E., 1976. Contnental margin off western Africa: Senegal to Portugal. Am. Assoc. Pet. Bull. 60, 819-878.

Vink, G.E., Morgan, W.J., Zhao, W.L., 1984. Preferential rifing of continents: a source of displaced terrains. J. Geophys. Res. 89, 10 $72-1 \bullet \cdot 76$

Vogt, P.R., 1974a. Volcano spacing fractures and thickness of the lithosphere. Earth Planet. Sci. Lett. 21, 235-252.

Vogt, P.R., 1974b. Volcano height and plate thicknesses. Earth Planet. Sci. Lett. 23, 337-348.

Watkins, J.S., Hoppe, K.W., 1979. Seismic reflection recomnaissance of the Atlanic margin of Morocco. In: Talwani, M., Hays, W., Ryan, W.B.F. (Eds.), Deep Drilling Results in the Atlanic Ocean: Continental Margins and Paleoenvironment. Am. Geophys. Union, Washington, pp. 205-217.

Watts, A.B., 1994. Crustal sucture, gravity anomalies and flexure of the lithosphere in the vicinity of the Canary Islands. Geophys. J. Int. 119, 648-666.

Watts, A.B., Peirce, C., Collier, J., Dalwood, R., Canales, J.P.,
Henstock, T.J., 1997. A seismic study of lithospheric flexure in the vicinity of Tenerife, Canary Islands. Earth Planet. Sci. Lett. 146, 431-447.

Weigel, W., Goldflam, P., Hinz, K., 1997. The crustal swucture of the Conception Bank. Mar. Geophys. Res. 3, 381-392.

Weigel, W., Wissmann, G., Goldflam, P., 1982. Deep seismic swucture (Mauretania and central Morocco). In: von Rad, U., Hinz, K., Samthein, M., Seibold, E. (Eds.), Geology of the NW African Continental Margin. Springer, Heidelberg, pp. 132-159.

White, W.M., McBimey, A.R., Duncan, R.A., 1993. Perology and geochemistry of the Galapagos Islands: Pormait of a pathological mantle plume. J. Geophys. Res. 98, 3-19 563.

Wigger, P., Asch, G., Giese, P., Heinsolm, W.D., El Alami, S.O., Ramani, F., 1992. Crustal sucture along a raverse across the Middle and High Atlas Mountains derived from seismic refraction studies. Geol. Rumdsch. 81, 237-248.

Williams, C.A., Hill, I.A., Young, R., White, R.S., 1990. Fracture zones across the Cape Verde Rise, NE Atlantic. J. Geol. Soc. London 147, 851-857.

Wilson, J.T., 1963. A possible origin of the Hawaiian Islands. Can. J. Phys. 41, 863-870.

Wilson, M., 1997. Thennal evolution of the central Atlanic passive margins: Continental break-up above a Mesozoic super-plume. J. Geol. Soc. London 154, 491-495.

Woodhead, J.D., 1992. Temporal geochemical evolution in oceanic in ra-plate volcanics: a case study from the Marquesas (French Polynesia) and comparison with other hotspots. Con rib. Mineral. Perol. 111, 458-467.

Wyss, M., 1980. Hawaiian rifts and recent Icelandic volcanism: expressions of plume generated radial stress fields. J. Geophys. 47, 19-22.

Wysession, M.E., Wilson, J., Bartkó, L., Sakata, R., 1995. In raplate seismicity in the Atlanic Ocean basin: a teleseismic catalog. Bull. Seismol. Soc. Am. 85, 755-774.

Ye, S., Canales, J.P., Rihm, R., Dañobeiria, J.J., Gallart, J., 1999. A crustal transect through the northern and northeastern part of the volcanic edifice of Gran Canaria, Canary Islands. J. Geodyn. 28, 3-26.

Zhang, Y.S., Tanimoto, T., 1992. Ridges, hotspots and their interaction as observed in seismic velocity maps. Nature $355,45-49$. 